\title{
Archaeological Investigations at the Christopher Columbus Italian Society Property and Columbus Park: 41BX1968, the Possible First Site of Mission San Antonio de Valero
}

Kristi Miller Nichols

Raba Kistner

Follow this and additional works at: https://scholarworks.sfasu.edu/ita

Part of the American Material Culture Commons, Archaeological Anthropology Commons, Environmental Studies Commons, Other American Studies Commons, Other Arts and Humanities Commons, Other History of Art, Architecture, and Archaeology Commons, and the United States History Commons

Tell us how this article helped you.

This Article is brought to you for free and open access by the Center for Regional Heritage Research at SFA ScholarWorks. It has been accepted for inclusion in Index of Texas Archaeology: Open Access Gray Literature from the Lone Star State by an authorized editor of SFA ScholarWorks. For more information, please contact cdsscholarworks@sfasu.edu. 
Archaeological Investigations at the Christopher Columbus Italian Society Property and Columbus Park: 41BX1968, the Possible First Site of Mission San Antonio de Valero

Creative Commons License

(c) (i) (9)

This work is licensed under a Creative Commons Attribution-NonCommercial 4.0 International License 


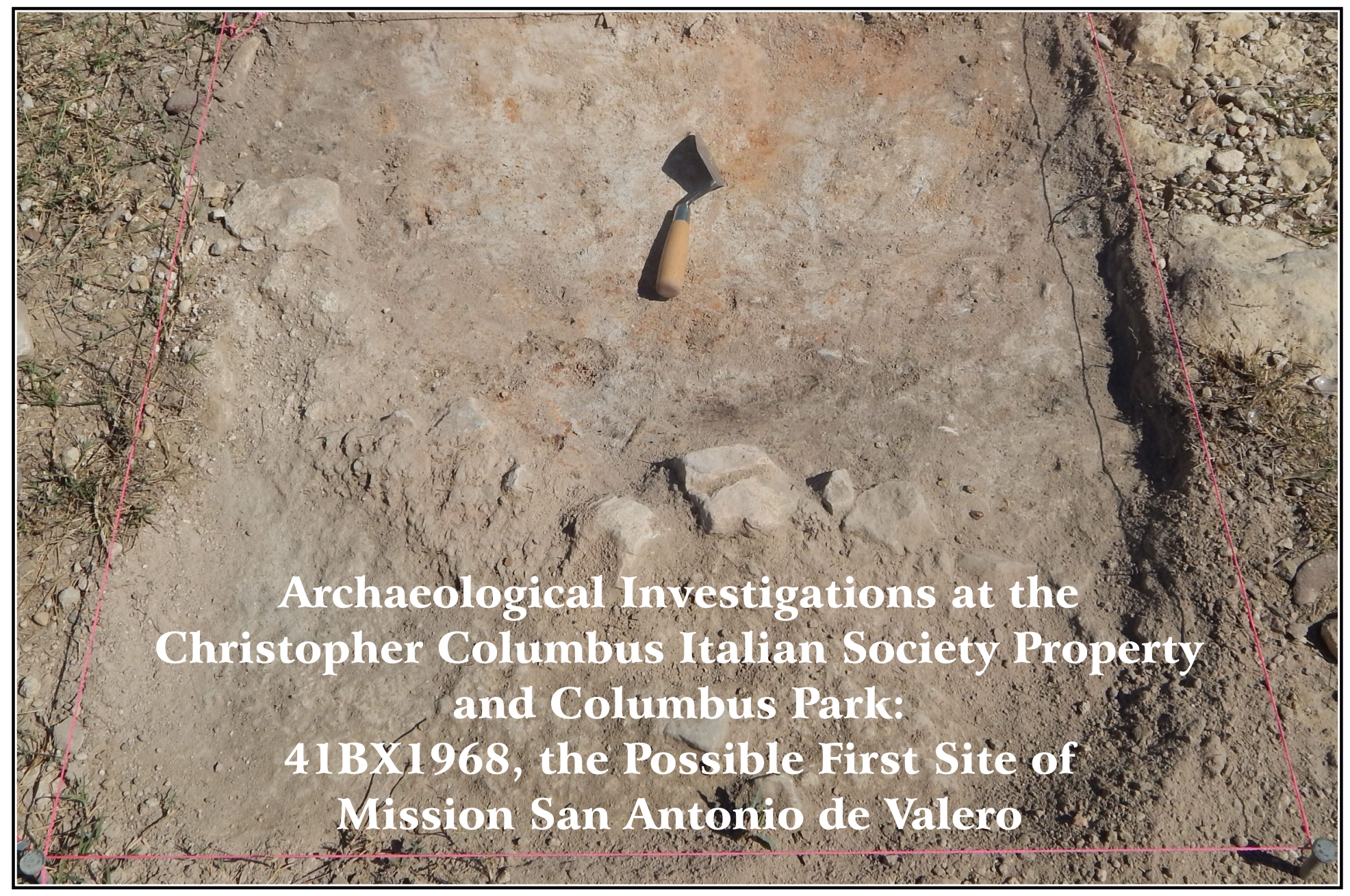

by

Kristi Miller Nichols

Texas Antiquities Committee Permit No. 6534

Non-Restricted

Principal Investigator

Raymond Mauldin

Original Principal Investigator

Steve A. Tomka

Prepared for:

San Antonio Conservation Society 107 King William Street

San Antonio, Texas 78204

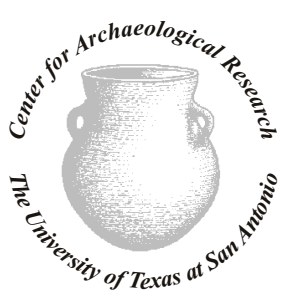

(C)2015
Prepared by:

Center for Archaeological Research The University of Texas at San Antonio One UTSA Circle

San Antonio, Texas 78249

Archaeological Report, No. 432 



\title{
Archaeological Investigations at the \\ Christopher Columbus Italian Society Property and Columbus Park: \\ 41BX1968, the Possible First Site of \\ Mission San Antonio de Valero
}

\author{
by \\ Kristi Miller Nichols
}

Texas Antiquities Committee Permit No. 6534

Principal Investigator

Raymond Mauldin

Original Principal Investigator

Steve A. Tomka

\section{Non-Restricted}

San Antonio Conservation Society

107 King William Street

San Antonio, Texas 78204
Center for Archaeological Research The University of Texas at San Antonio One UTSA Circle

San Antonio, Texas 78249

Archaeological Report, No. 432 



\begin{abstract}
:
In May of 2013, the Center for Archaeological Research of The University of Texas at San Antonio was contracted by the San Antonio Conservation Society (SACS) to explore the Spanish Colonial archaeological deposits and a feature that were recently identified in a lot owned by the Christopher Columbus Italian Society and next to the San Francesco di Paola Church in north-central San Antonio, Bexar County, Texas. Based on a number of historical descriptions, the deposits were thought to possibly be associated with the first location of Mission San Antonio de Valero that was established in 1718. Thirty-one shovel tests were excavated in Columbus Park and on property owned by the Christopher Columbus Italian Society near the church. In addition, three test units were excavated at a location downhill from the church on property owned by the Christopher Columbus Italian Society. The archaeological investigations were conducted under Texas Antiquities Permit No. 6534. Steve Tomka served as the Original Principal Investigator, and Kristi Miller Nichols served as Project Archaeologist. The Permit is currently held by Dr. Raymond Mauldin.
\end{abstract}

Surface collection in the open field and in the vicinity of the church produced a small quantity of Spanish Colonial Period material, including wrought iron nails, a majolica ceramic fragment, a trade bead, and melted lead. Shovel tests revealed that the upper $60 \mathrm{~cm}$ of soil in the park contains mostly modern and some early twentieth-century materials. Investigations found no evidence of Mission San Antonio de Valero within Columbus Park. Test unit excavations in the Christopher Columbus Italian Society's property produced fragments of majolica ceramics affiliated with the Spanish Colonial Period and lead-glazed Galera wares of probable Colonial age.

While a large proportion of the cultural materials recovered from surface and the shovel tests does consist of nineteenthand twentieth-century materials, the remainder includes a variety of Spanish Colonial artifacts such as tin- and lead-glazed ceramics, bone-tempered sherds, a trade bead, and fragments of wrought iron nails. It is likely that the materials have been re-deposited from the upper portion of the landform where the church and hall had been erected in the late 1920s. In addition, the western portion of the tract had been graded prior to the construction of a paved parking lot, and this further disturbed any buried cultural deposits. The cultural material that is affiliated with the Spanish Colonial Period is overwhelmed by artifacts dated to later periods. This is somewhat expected given the short-lived history of Mission San Antonio de Valero at its first location. Based on archival descriptions, this area matches at least one distance given for the location of the mission in relation to the presidio and villa that are believed to have been located near modern-day San Pedro Park. While it is possible that this location is the first site of Mission San Antonio de Valero, additional archaeological investigations will be required to verify that possibility. It is necessary to obtain larger samples of Colonial materials and architectural evidence that would be consistent with the structures and features likely associated with the site during the first few months of its occupation. Unfortunately, the areas that could hold such artifacts and features are likely to be under the footprint of the church proper and under a nearby asphalted parking lot. It is recommended that if and when the asphalted parking lot is redeveloped and the asphalt removed, archaeological investigations be carried out in the area to determine if any Spanish Colonial Period materials are present. It is the CAR's understanding that a significant amount of fill was introduced to the area to level it prior to the construction of the parking lot. The fill was borrowed from the grassy field where the testing investigations took place. Furthermore, archaeological investigations are recommended if any future opportunities arise to investigate the crest of the hill, particularly under the footprint of the church and hall. 



\section{Table of Contents:}

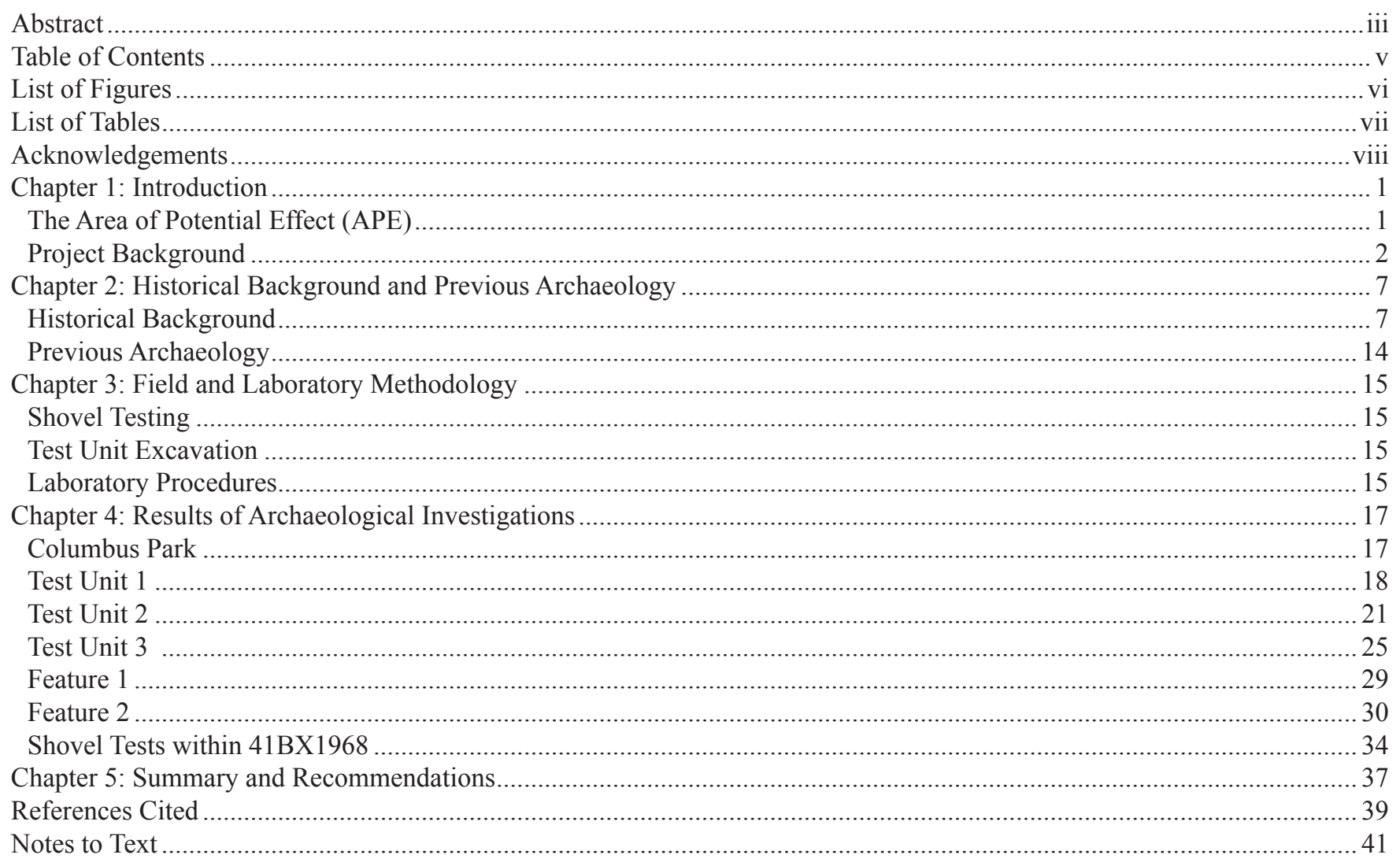




\section{List of Figures:}

Figure 1-1. The APE on the combined San Antonio East (1988-133) and San Antonio West (1998-132) USGS 7.5-minute quadrangle maps

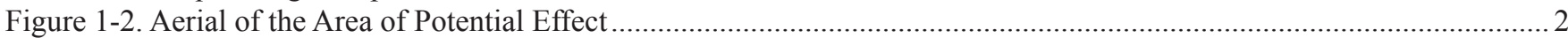

Figure 1-3. Artifacts noted on the surface in the grass-covered field near the northern parking lot of the San Francesco di Paola Church. Note fragments of bone-tempered ceramics in center of image ........................................................... 3

Figure 1-4. Selected artifacts noted on the surface of eroding area near parking lot owned by the Christopher Columbus Italian Society. Note blue glass trade bead at top of image and burned clay at left margin....

Figure 1-5. Additional artifacts recovered from the surface of site 41BX1968. Note wrought iron nail with rose head (a), melted lead fragments (b), and polychrome majolica fragment (c)....

Figure 1-6. Rock alignment and red soil noted in the vicinity of the surface collected artifacts. Photograph taken following the removal of loose soil in the area.

Figure 2-1. The project area on the combined San Antonio East (1953) and San Antonio West (1953)

USGS 7.5-minute quadrangle map

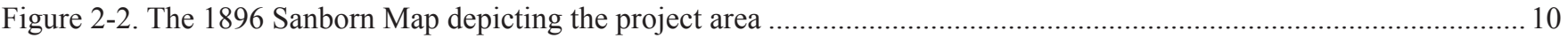

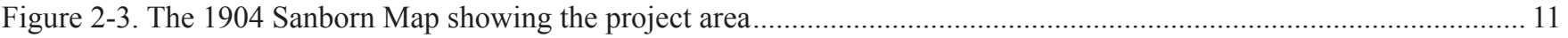

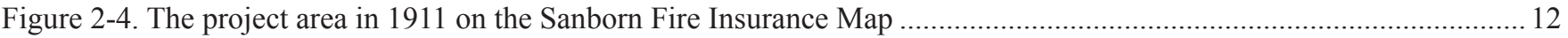

Figure 2-5. The 1911-1950 Sanborn Map depicting the project area showing the constructed church ................................. 13

Figure 2-6. Plat showing the planning of IH-35 as part of the Urban Renewal Project ........................................................ 14

Figure 4-1. Location of shovel test and test units excavated within the project area. Red circles indicate shovel tests within Columbus Park. White circles indicate shovel tests on property owned by the Christopher Columbus

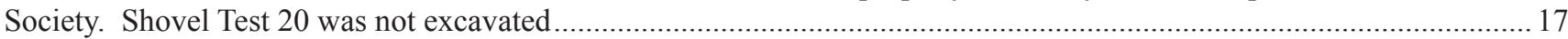

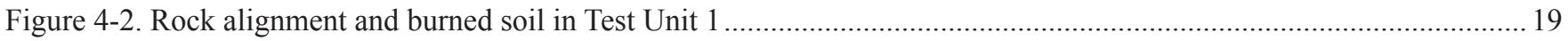

Figure 4-3. Profile of the north wall of Test Unit 1. Feature 1 consists of the ash lens and Strata 2 .................................... 19

Figure 4-4. Test Unit 2 looking north. Note that the last level (Lev. 7) was excavated only in the southern half of the unit.... 21

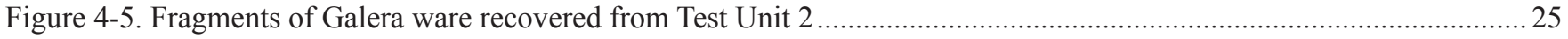

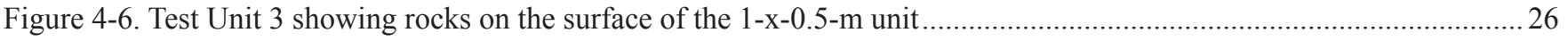

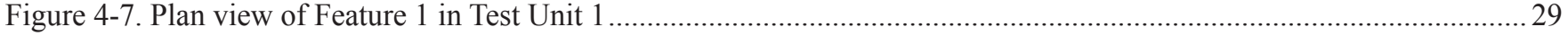

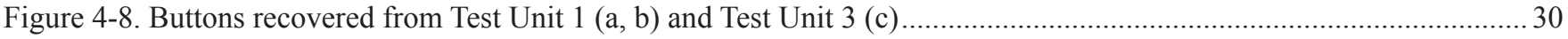

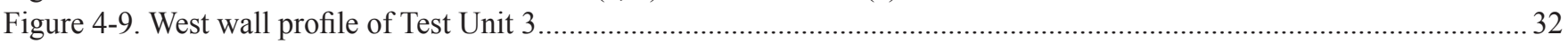

Figure 4-10. Fragment of Puebla Blue on White majolica recovered from Feature 2 ........................................................... 34

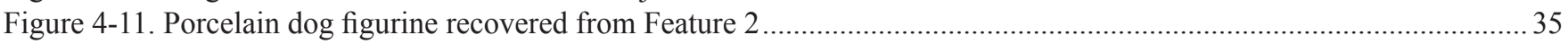

Figure 4-12. Porcelain boy figurine recovered from Feature 2 .................................................................................. 35

Figure 4-13. Marbles recovered from the excavations. The glass marble was from Test Unit 2. The china marble was from Feature 2 in Test Unit 3 


\section{List of Tables:}

Table 1-1. List of Artifacts Recovered from the Surface of Grass-Covered Field in the Vicinity of the San Francesco di Paolo Church...... 4

Table 4-1. Shovel Tests Excavated in Columbus Park

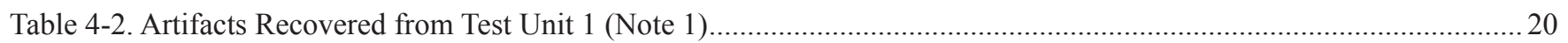

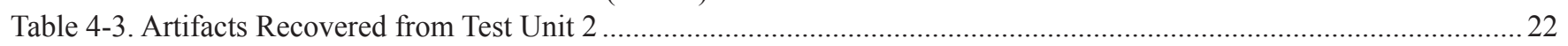

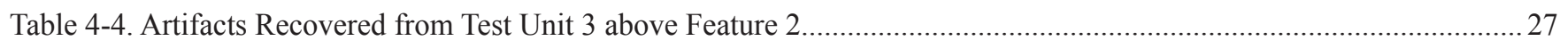

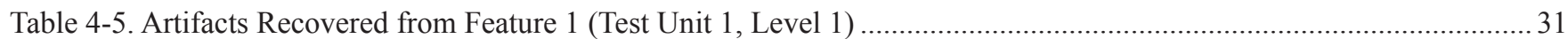

Table 4-6. Artifacts Associated with Feature 2 in Test Unit 3 (Note 2) ............................................................................ 32

Table 4-7. Artifacts Recovered from Shovel Tests on Christopher Columbus Italian Society's Property................................ 36

Table 5-1. Artifacts Collected at the Site Potentially Associated with the Spanish Colonial Period..................................... 38 


\section{Acknowledgements:}

The author would like to thank many people for their assistance during the course of the project. Thanks go to Kay Hindes, San Antonio City Archaeologist, who was present during much of the excavation and offered help and insight. Also, Mark Denton of the Texas Historical Commission was present on the first day of excavations and offered his insight as well as help with screening and surface collection. Special thanks go to Frank Monaco of the Christopher Columbus Italian Society for granting the CAR permission to excavate on the Society's property and to use of the hall's facilities.

The field crew consisted of Tyrone Tatum, Sarah Wigley, Matthew Colvin, and Mark Luzmoor. Melissa Eiring processed and catalogued the artifacts recovered from the site. Dr. Steve Tomka served as Principal Investigator for the project and provided much helpful guidance through the course of the investigations. Marybeth Tomka conducted the final curation of the material that remains at the CAR. Rick Young and Leonard Kemp prepared the figures for the report. Kelly Harris edited the report draft for final production. Thanks go to these people who have participated in the completion of the project. 


\section{Chapter 1: Introduction}

The Center for Archaeological Research (CAR) at The University of Texas at San Antonio (UTSA) was contracted by the San Antonio Conservation Society (SACS) to explore archaeological deposits and a feature that had been recently identified in a parking lot owned by the Christopher Columbus Italian Society and located next to San Francesco di Paola Church in north-central San Antonio, Bexar County, Texas. These deposits were believed to possibly relate to the first location of Mission San Antonio de Valero that was established in 1718. The Area of Potential Effect (APE) is shown in Figure 1-1, the combined San Antonio East (1988133) and San Antonio West (1998-132) USGS 7.5-minute quadrangle maps, and on Figure 1-2, an aerial photograph.

\section{The Area of Potential Effect (APE)}

The APE is on a prominent hill overlooking San Pedro Creek. The project area is divided into two sections owned by different entities. The northern half of the hill consists of parking lots and open fields owned by the Christopher Columbus Italian Society, and the very top of the hill is the site of the publicly owned Columbus Park. The Christopher Columbus Italian Society tract is adjacent to the San Francesco di Paola Catholic Church. The church was built in 1927 on land donated from the City of San Antonio. The Italian Hall, the home of the Christopher Columbus Italian Society, was erected in 1928 on grounds adjacent to the

Restricted Image

Figure 1-1. The APE on the combined San Antonio East (1988-133) and San Antonio West (1998132) USGS 7.5-minute quadrangle map. 
Restricted Image

Figure 1-2. Aerial of the Area of Potential Effect.

church. The construction of the two structures, including their foundations, basements, and the subsequent paved parking lot to the west of the church resulted in extensive subsurface disturbances to any buried cultural materials that were present at the location. Parishioners and Society members recall that people picked up a large number of artifacts from the area as the ground was disturbed during the construction of a later addition to the church. From the descriptions, many of these artifacts consisted of majolica ceramics and various metal objects. Later improvements, such as the construction of the second paved parking lot to the north of the church, resulted in additional significant ground disturbing activities to the property. For instance, the construction of the northern parking took place after top soil from the northwest corner of the tract was graded and redistributed across the northeastern portion of the tract to raise the grade and provide a reasonably flat subsurface for the paved lot. Landscaping, including the flower beds, tree plantings, and improvements, such as sidewalks, resulted in additional impacts to buried cultural deposits.

The archaeological investigations detailed in this report focused on the northwest corner of the tract in the previously mentioned unpaved, grassy field that served as borrow area for fill for the northern parking lot of the church. In addition, City-owned Columbus Park was also investigated since the location was at the crest of the hill overlooking San Pedro Creek, and it appeared that it may have undergone less severe disturbances. Permission to investigate the park was granted by the City of San Antonio, whereas permission to investigate the Society's property was granted by Frank Monaco at the Christopher Columbus Italian Society. No investigations were carried out on property owned by the San Francesco di Paola Catholic Church.

At the time of the first visual inspection of the APE in February 2013, the grounds owned by the Society consisted of a field carpeted with short grasses and patches of barren ground particularly near the southeastern corner of the field in the vicinity of the northern paved parking lot. The inspection of the grounds within Columbus Park revealed no historic or prehistoric cultural deposits on the surface.

\section{Project Background}

A small number of artifacts were noted on the surface during three different visits to the area in February 2013. On February 12, during a brief on-site visit, City Archaeologist Kay Hindes located a number of Colonial artifacts on the Christopher Columbus Italian Society property that were given to Frank Monaco of the Christopher Columbus Italian Society. Figures 1-3 through 1-5 show samples of 


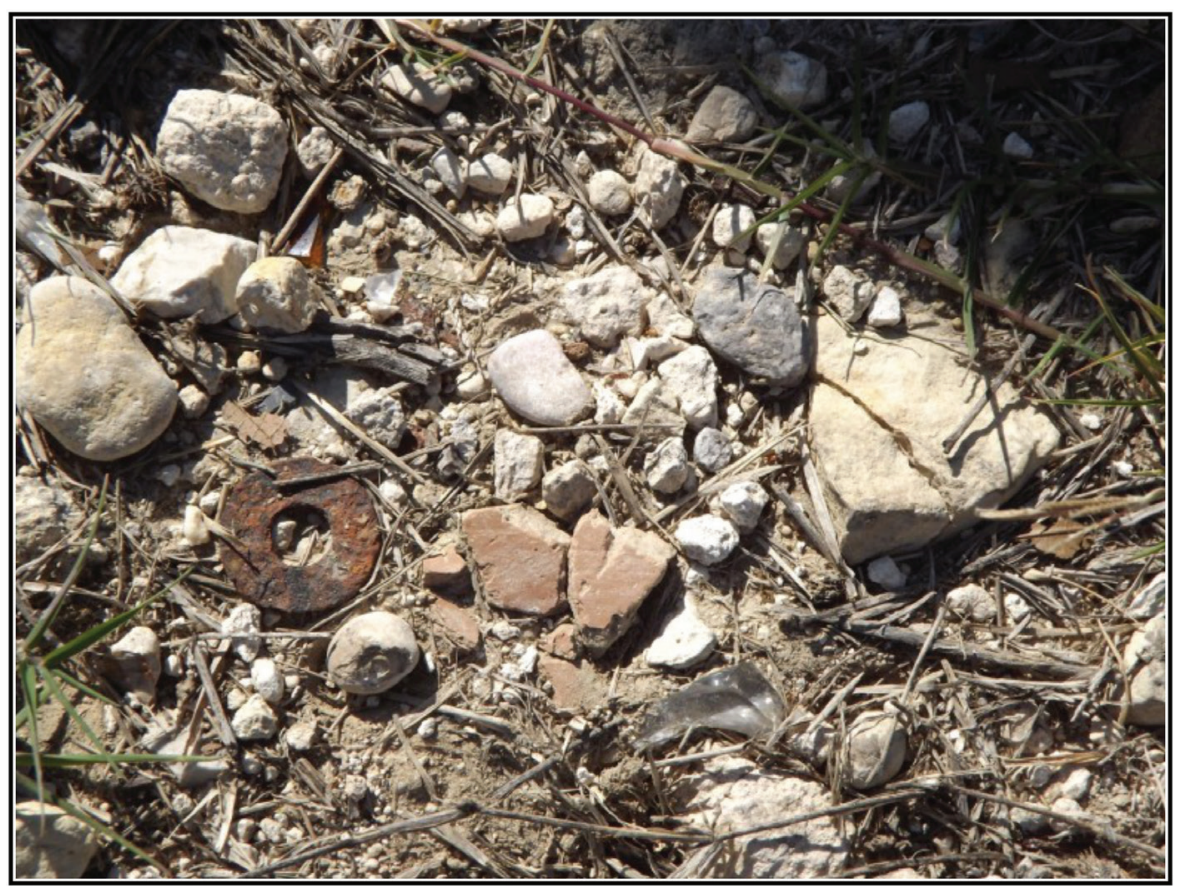

Figure 1-3. Artifacts noted on the surface in the grass-covered field near the northern parking lot of the San Francesco di Paola Church. Note fragments of bone-tempered ceramics in center of image.

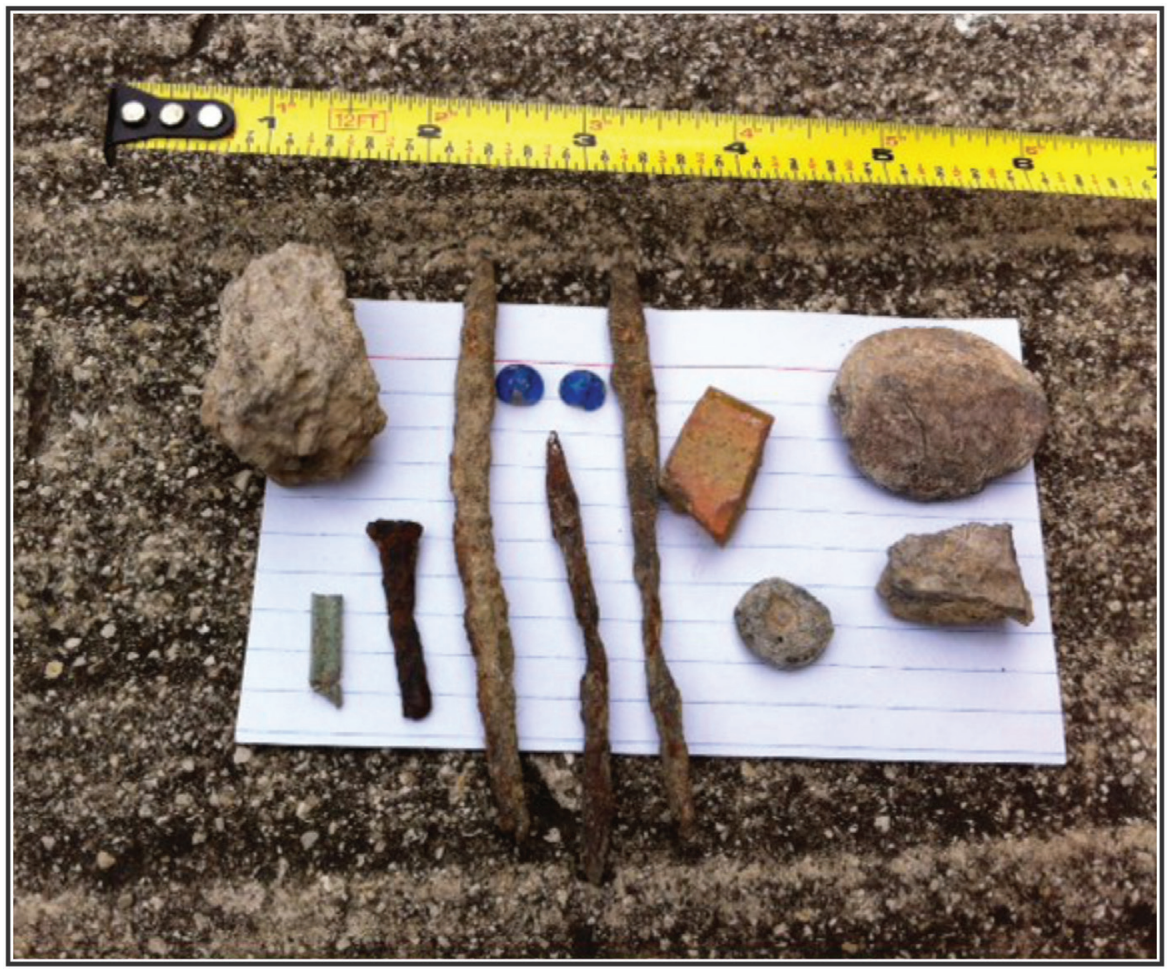

Figure 1-4. Selected artifacts noted on the surface of eroding area near parking lot owned by the Christopher Columbus Italian Society. Note blue glass trade bead at top of image and burned clay at left margin. 


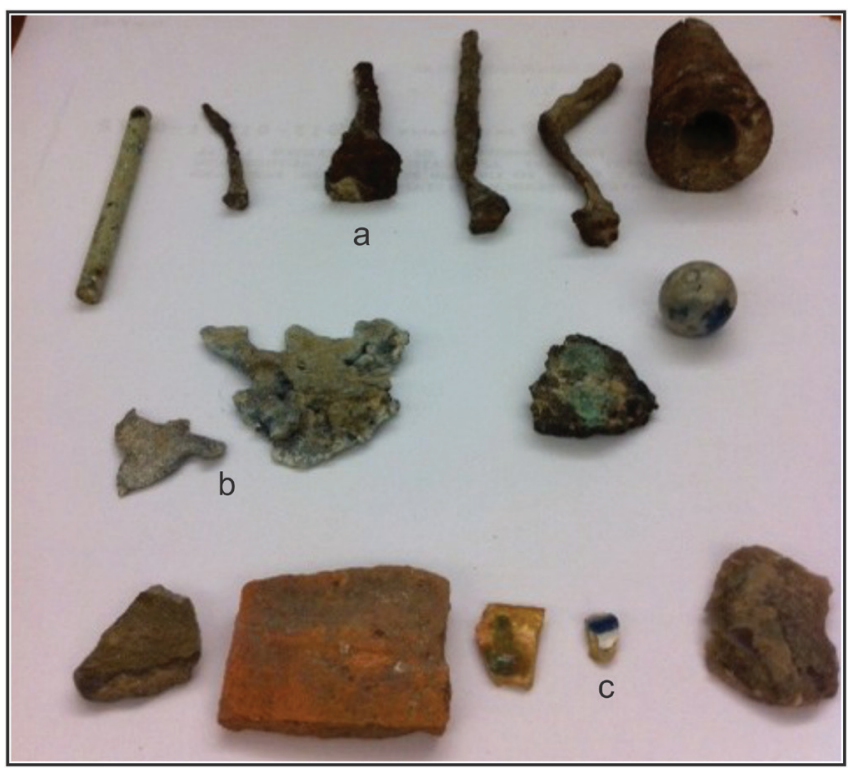

Figure 1-5. Additional artifacts recovered from the surface of sited 41BX1968. Note wrought iron nail with rose head (a), melted lead fragments (b), and polychrome majolica fragment (c).

these items. The artifacts consisted of wrought iron nails, at least one of which had a rose head, one small fragment of majolica, pieces of melted lead, lead-glazed ceramic wares, and one piece of lithic debitage (Figure 1-5). During a second visit to the site, Kay Hindes found additional artifacts on surface. They included one blue glass trade bead, a lead disk, additional lead-glazed wares, two fragments of burnt clay or daub, and fragments of wrought iron nails (Figure 1-4). Yet a subsequent visit by Kay Hindes and Steve Tomka of the CAR noted additional Colonial artifacts on the surface. These artifacts consisted of three fragments of what appeared to be bone-tempered native-made ceramics, numerous fragments of lead-glazed Colonial wares, a small piece of tin-glazed blue on white majolica, additional fragments of wrought iron nails, mid-twentieth-century items, such as a washer and a metal button, fragments of lead, and clear window glass. Unfortunately, the majolica fragment is too small to place into a definitive Spanish Colonial typology. Table 1-1 lists the artifacts noted during the different visits to the site.

In addition to the artifacts collected from the surface, during the site visits, a number of rocks were noted exposed on the ground surface. These rocks appeared to be limestone, and some seemed to have been shaped suggesting that they may have been quarried. The rocks seem to form a rough alignment reminiscent of a corner. Furthermore, close inspection of the ground surface on what appeared to be the inside of this alignment revealed patches of fire-reddened soil suggesting that the ground had been exposed to heat (Figure 1-6). Nearby pieces of burned daub substantiated this conclusion.

A fourth visit to the site, made by Mark Denton of the Texas Historical Commission (THC) accompanied by Kay Hindes, resulted in the identification and recovery of more artifacts, with some clearly affiliated with the Spanish Colonial Period,

Table 1-1. List of Artifacts Recovered from the Surface of Grass-Covered Field in the Vicinity of the San Francesco di Paolo Church

\begin{tabular}{|c|c|c|}
\hline Artifact Category & Count & Temporal Affiliation \\
\hline Bone tempered ceramics & 5 & Potentially Colonial \\
\hline Blue glass trade bead & 2 (refit into 1 complete bead) & Potentially Colonial \\
\hline Bead & 1 & Potentially Colonial \\
\hline Possible copper ring with blue gems & 1 & Unknown \\
\hline Jewelry fragment with blue inset & 1 & Colonial \\
\hline Polychrome majolica & 1 & Colonial \\
\hline Wrought iron nails/fasteners & 7 & Colonial \\
\hline Lead-glazed ceramics & 7 & Late $19^{\text {th }}$ to $20^{\text {th }}$ Century \\
\hline Porcelain doll/Figurine head fragment & 1 & Unknown \\
\hline Unidentified copper & 2 & Unknown \\
\hline Lead fragments & 5 & $19^{\text {th }}$ to $20^{\text {th }}$ Century \\
\hline Metal hook & 1 & Unknown \\
\hline Metal tack & 1 & Unknown \\
\hline Metal fragments & 6 & $19^{\text {th }}$ Century \\
\hline Cut nails & 7 & \\
\hline
\end{tabular}




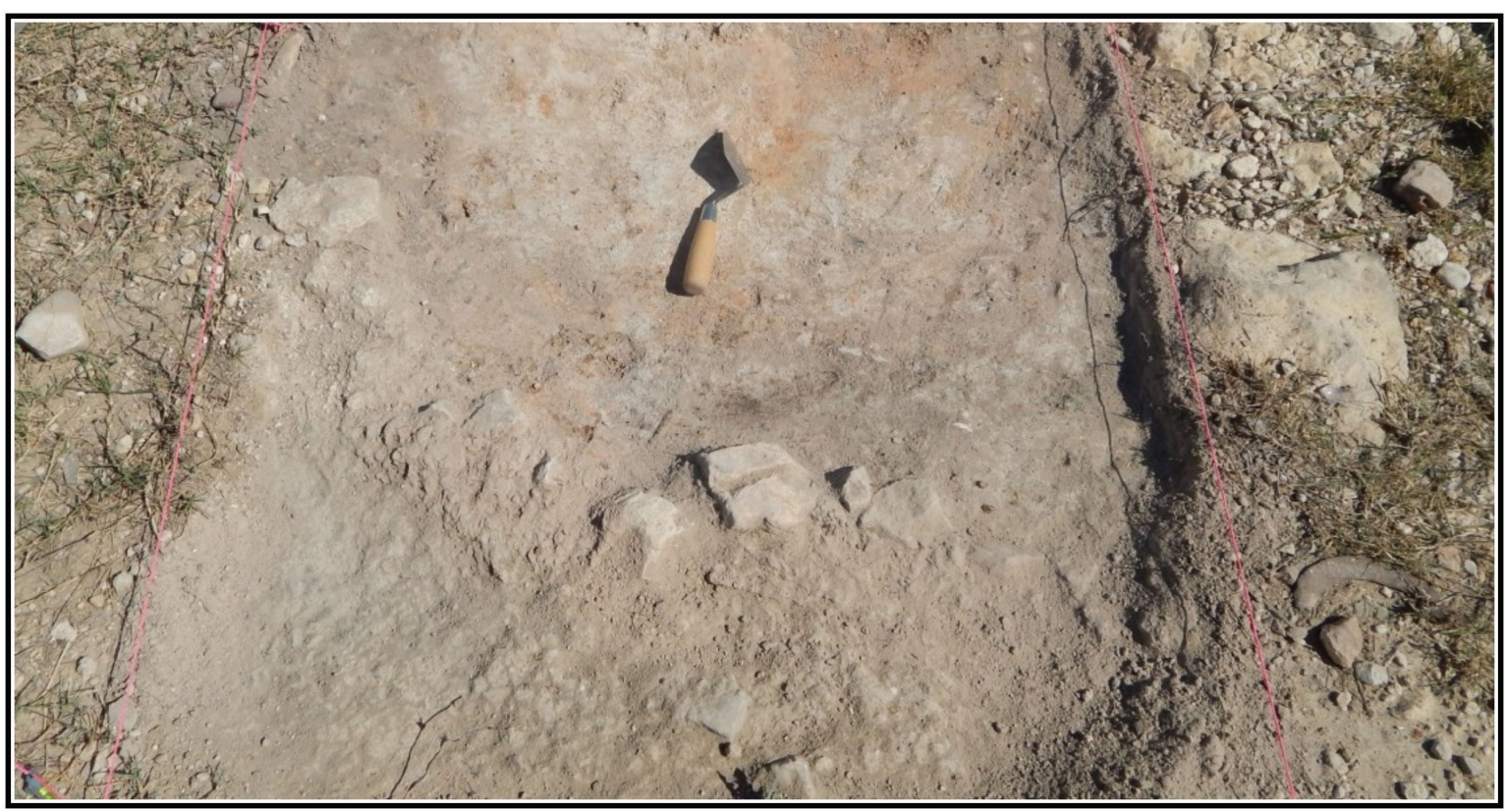

Figure 1-6. Rock alignment and red soil noted in the vicinity of the surface collected artifacts. Photograph taken following the removal of loose soil in the area.

such as additional lead-glazed ceramic fragments. During the visit, additional limestone rocks were noted eroding out of the ground suggesting that the rock alignment observed earlier was larger than originally thought.

During brief discussions with Frank Monaco of the Christopher Columbus Italian Society, it became clear that the Society was preparing plans to develop the property located to the north of the church, including the paved parking lot and the grassy field to its west. In addition, the Christopher Columbus Italian Society plans to construct a new entrance to the Christopher Columbus Park, which would impact a small portion of the park itself. Given the recovery of Spanish Colonial artifacts, coupled with the possibility that the stone alignments may represent architectural remains, the City Archaeologist asked that archaeological investigations be conducted in both locations to determine if the hill is the first location of Mission San Antonio de Valero.

Although the number of artifacts was small and the stone alignment consisted of only a few rocks, the site and the finds could not be ignored given the potential that they may represent the remains of the first location of Mission San Antonio de Valero. Furthermore, the sparseness of the remains was consistent with expectations given that the mission was only occupied for one or two years at its first location before being moved either once or more likely twice before it was finally established at its current location in 1724 (Cox 2005; Habig 1990). Due to the enormous significance of the first site of Mission San Antonio de Valero to the history of San Antonio, it was felt that any evidence that might point to the location of the site should be fully investigated.

The late Anne Fox, a highly experienced and long-time employee of the CAR, had mentioned to Steve Tomka (personal communication, 2009) of the CAR that she suspected the first location of the Mission San Antonio de Valero was on the hill adjacent to the church and in the vicinity of Columbus Park. This opinion was also shared by the late Wayne Cox, a respected local historian and also former staff member of the CAR. Fox and Cox appear to have arrived to their conclusion that the San Francesco di Paolo Church sits on the mission's first location from having carefully scrutinized the historic records related to the establishment of Mission San Antonio de Valero.

Prior to the initiation of the CAR's work, a site survey form was prepared and submitted to the Texas Archeological Research Laboratory (TARL). The TARL assigned trinomial 41BX1968 to the site. As part of this project, a site revisit form is being submitted to the THC's Texas Archeological Site Atlas (TASA) to add the information and findings of the current project. 



\section{Chapter 2: Historical Background and Previous Archaeology}

\section{Historical Background}

The vicinity of San Pedro Springs was first described during the Espinoza-Olivares-Aguirre expedition in 1709 (Cox 2005). When the expedition members came upon the location on April 13, they noted its ample output of water that emanated from several springs along stepped limestone ridges and that this provided sufficient water to support an entire town. Governor Alarcón intended that the first of two frontier towns be established at the San Antonio River. The viceroy had ordered that Alarcón send 30 settler families, artisans as well as the missionaries, and soldiers to the new town. The families were to receive land, livestock, supplies, and a salary (de la Teja 1995). However, less than 30 families volunteered to be part of the venture, and the party that was assembled consisted of an engineer, a stone mason, a blacksmith, women, and children.

The Alarcón party left Rio Grande del Norte on February 16, 1718. Fr. Pedro de Mezquía, who had been a missionary in Coahuila and accompanied the Alarcón expedition of 1718, kept a diary of the events. According to the Mezquía diary concerning the Alarcón expedition, the group consisted of seventy-two individuals (Hoffman 1938). Three people were described as "religious" and would likely be the padres that would help to establish the new mission in the San Antonio area (Hoffman 1938). The remainder of the party consisted of soldiers and their families, civilians, and mule team leaders. In addition to the people, the expedition also brought sheep, cattle, goats, horses, and chicken to the frontier (Hoffman 1938). Father Olivares had been increasingly impatient as Alarcón assembled the group and performed necessary duties in the Capital. Olivares had left Saltillo at an earlier date but could not leave the San Juan Bautista area as Captain Ramon stalled to give any soldiers escorting his group additional time in San Antonio (Weddle 1968). Olivares was forced to wait until Alarcón arrived at the Presidio. Although Olivares had shown so much impatience, Alarcón made the entry into Texas first, leaving days prior to Olivares. The expedition party arrived near the San Antonio River on April 25, 1718 (Hoffman 1938; Weddle 1968). Mezquía indicated that the party came to the "first spring of San Antonio which is about six leagues distant" (Hoffman 1938). The first spring is believed to be San Pedro Springs. Olivares arrived on May 1.

During the first week at the site, Alarcón went on several excursions to investigate the surrounding land (Hoffman 1938). His group found that there was a good water source from both the springs at San Pedro and the headwaters of the San Antonio River. Mezquía noted that there was enough water "for maintaining a populous villa and two or three missions" (Hoffman 1938). Alarcón performed the necessary rituals to make claim to the land and allowed Olivares to perform the first mass. Mezquía noted that the location of the new mission "is near the first spring, half a league from a high ground and adjoining a small thicket of live oaks" (Hoffman 1938:318). A provisional hut was constructed by Olivares to serve as the mission's first location and a place to hold mass (Cox 2005). The establishment of Mission San Antonio de Valero occurred on May 1, 1718 (Habig 1968, 1990; Weddle 1968). The location was to be temporary, being used until the Native American inhabitants returned from their seasonal hunting and gathering trips (Cox 2005). Days later on May 5, 1718, Alarcón established the Villa de Béxar approximately $3.7 \mathrm{~km}$ (2.3 mi.) from the San Antonio River (de la Teja 1995; Hoffman 1938:318). Mezquía noted that the villa was located between the creek and the river, and the mission was placed at a distance from the villa (Cox 2005).

In contrast to Mezquía's account, Fr. Francisco de Céliz, a missionary from Coahuila, who served as the official diarist of the expedition, wrote that the site of the first mission was $3.2 \mathrm{~km}$ (1.97 mi.) south of the springs, along San Pedro Creek, on the west side of the San Antonio River.

This site is henceforth destined for the civil settlement and the soldiers who are to guard it, as well as for the site of the mission of San Antonio de Valero, established by the said governor about three-fourths of a league down the creek [Hoffman 1935:49].

The mission stayed at the first location for about a year before being moved to the east bank of the San Antonio River (Habig 1990).

There are discrepancies in the distances provided by the accounts, although both indicate that the villa was established in the immediate vicinity of "the first spring" (Hoffman 1938:318), which most historians believe is San Pedro Springs (Cox 2005). In addition, it is not stated whether the distances were measured along the stream channel/meander or in a straight line. However, it is possible that the distances were indeed on-the-ground measurements rather than straight-line estimates. Later historians (Cox 2005; Habig 1968, 1990) describe the mission's first location as being on the west bank of the San Antonio River based on the fact that later documents state that the mission was moved to the east bank. 
Using the Mezquía account, the location of the first site of the mission can be estimated by measuring the half-league distance starting at the high ground from above San Pedro Springs and heading south along the creek channel. Although the channel is partially hidden under IH-35 today, its original path, illustrated on historic maps (cf. Koch's 1886 Bird's Eye View of San Antonio; J.J. Olsen and Son Map of San Antonio, 1889), has not changed significantly in this stretch of the creek. Hoffman, in his translation of the Céliz diary, states that in Spanish America, the judicial league was the standard of measurement, representing 4,190 m (Hoffman 1935:91). Using this unit of measurement, the first site of the mission should be roughly $2,095 \mathrm{~m}$ downstream of the high ground behind the springs. Beginning the measurement from above the Springs and measuring along the channel of the creek yields roughly $2,110 \mathrm{~m}$ to the landform on which the San Francisco di Paola Church sits (Figure 2-1).

The mission and villa appeared to have stayed at these initial locations during the first year. Olivares constructed his temporary church of mud and brush "on a small knoll some 30 feet above the creek's flood plain, well away from the corrupting influences of the military and civilian settlement" (Cox 2005). By winter, the mission had Native American

Restricted Image

Figure 2-1. The project area on the combined San Antonio East (1953) and San Antonio West (1953) USGS 7.5-minute quadrangle map. 
groups assembling at its location. Alarcón had left San Antonio for East Texas in the fall, returning with additional supplies in January of 1719. Accounts indicate that he was happy to see the Native Americans gathered at the mission site upon his return (Cox 2005; Habig 1968). Céliz noted in his diary that the Native Americans appeared to have been instructed in the faith and assembled when called by the church bell (Hoffman 1935:86). Alarcón distributed gifts and appointed positions to the chiefs (Hoffman 1935).

The construction of acequias commenced soon after the mission and villa were established in 1718. Mezquía's reports on the location of the mission's acequia indicated that the second, more permanent site for the mission had been determined (Cox 2005; Hoffman 1935; Hoffman 1938). In the summer of 1719, Olivares moved Mission Valero to the east side of the river (Habig 1968, 1990). After it was abandoned, the first site of Mission Valero likely was an uninhabited residential area until the late 1800s. The second location is often believed to be the spot on which St. Joseph's Church currently stands. Research conducted by Father Habig (1968, 1990) found that a stone chapel had been constructed at the second mission location. Records indicated that the chapel stood until 1756 and was referred to as Capilla de la Santa Cruz (Habig 1990).

Mission Valero was moved to its third and final location in 1724 after hurricane-associated storms destroyed the construction at the second location (Cox 2005; Habig 1990). The third location was approximately $0.2 \mathrm{~km}(0.12 \mathrm{mi}$.) from the second site (Habig 1990).

It appears that the property under investigation was sold to José Casiano by J.M. Devine (Mayor of San Antonio) in August of 1849 (Bexar County Deed Records [BCDR] H1:282-283). In 1861, a portion of the property was conveyed to Cesario Torres (BCDR S2:101). Several lawsuits were filed against Torres, causing him to sell the property via a Sheriff's Deed dated February 1909 (BCDR 304:405-406). Torres' heirs appear to have regained ownership in 1916 as part of a Quit-Claim Deed (BCDR 493:392-393). Several years later, the heirs of Torres also lost the property in a lawsuit. The property was sold as a Quit-Claim Deed to Bernard Franza on June 10, 1925 (BCDR 831:256). A Receiver's Deed indicated that the property was sold in a private sale according to the court order. Charles Max Uhl conveyed the property as part of the judgment against the Torres heirs to Bernard Franza for a sum of \$7,000 (BCDR 831:256-257). Franza conveyed the property to a group of people in June of 1926. The group included A. Altobelli, B. Catalani, Paul Broggi, Frank Talerico, Joe DiCarlo, C. Fecci, G. Gerodetti, and Salvatore Granato (BCDR 891:541-543). This group later conveyed the property to the Christoforo Columbus Society, of which they were all members (BCDR 953:320-321). It appears that there are several spellings of "Christopher" used during the various deed transactions. Each account that is discussed uses the version as how it appeared in the deed records. The property came under the ownership of the Society in June of 1927. In October, the deed was amended to reflect that the name of the society was the Christofer Columbus Italian Society (BCDR 979:356-357).

The Christopher Columbus Italian Society, which had first been known as "Societa Italiana Cristoforo Colombo," was chartered on May 14, 1890. According to its history, the Christopher Columbus Italian Society donated the land on which the Italian community constructed San Francesco di Paola in 1927. The next year, the Christopher Columbus Italian Society opened the first Italian Hall located adjacent to the church (Christopher Columbus Italian Society 2013). In 1957, the Christopher Columbus Italian Society donated a statue of Christopher Columbus to the City of San Antonio. The City placed the statue within Columbus Park, which is located to the south of the church and hall.

Archival research revealed that the park had been called Franklin Square as early as 1881 (San Antonio Municipal Archives [SAMA] 2013a). Early Sanborn maps also show the park as Franklin Square. It appears that the name was changed around the same time that the statue was dedicated. Franklin Square appears on the 1892 key map, but there are not detailed pages for the area. This is the earliest Sanborn map on which Franklin Square appears; earlier maps do not illustrate the current project area. The 1896 Sanborn Map depicted both Franklin Square and the area the Christopher Columbus Italian Society would later obtain (Figure 2-2). Close inspection of the map found that two adobe structures were present near the area where the test units were excavated during this project (Figure 2-2). Both adobe structures were small, one-story, rectangular buildings, and the structures were labeled as dwellings.

The 1904 Sanborn Map also shows the park as Franklin Square (Figure 2-3). The square exhibits a series of paths that lead to a central circle. It appears that at least one of the adobe structures is no longer standing in 1904 (Sanborn 1904, Vol.1, Sheet 50). There is one structure present that is in a similar location, but it is not labeled as "adobe" on this version of the Sanborn Fire Insurance Maps. The 1911-1924 Sanborn Map depicts the project area in 1911 (Sanborn 1911-1924, Vol.1 1911, Sheet 26; Figure 2-4). The park is labeled as Franklin Square. It appears that the adobe structure is no longer standing. Additional dwellings were constructed along N. Laredo Street. The entire block appears to be a residential area. A large structure and a few smaller dwellings were 


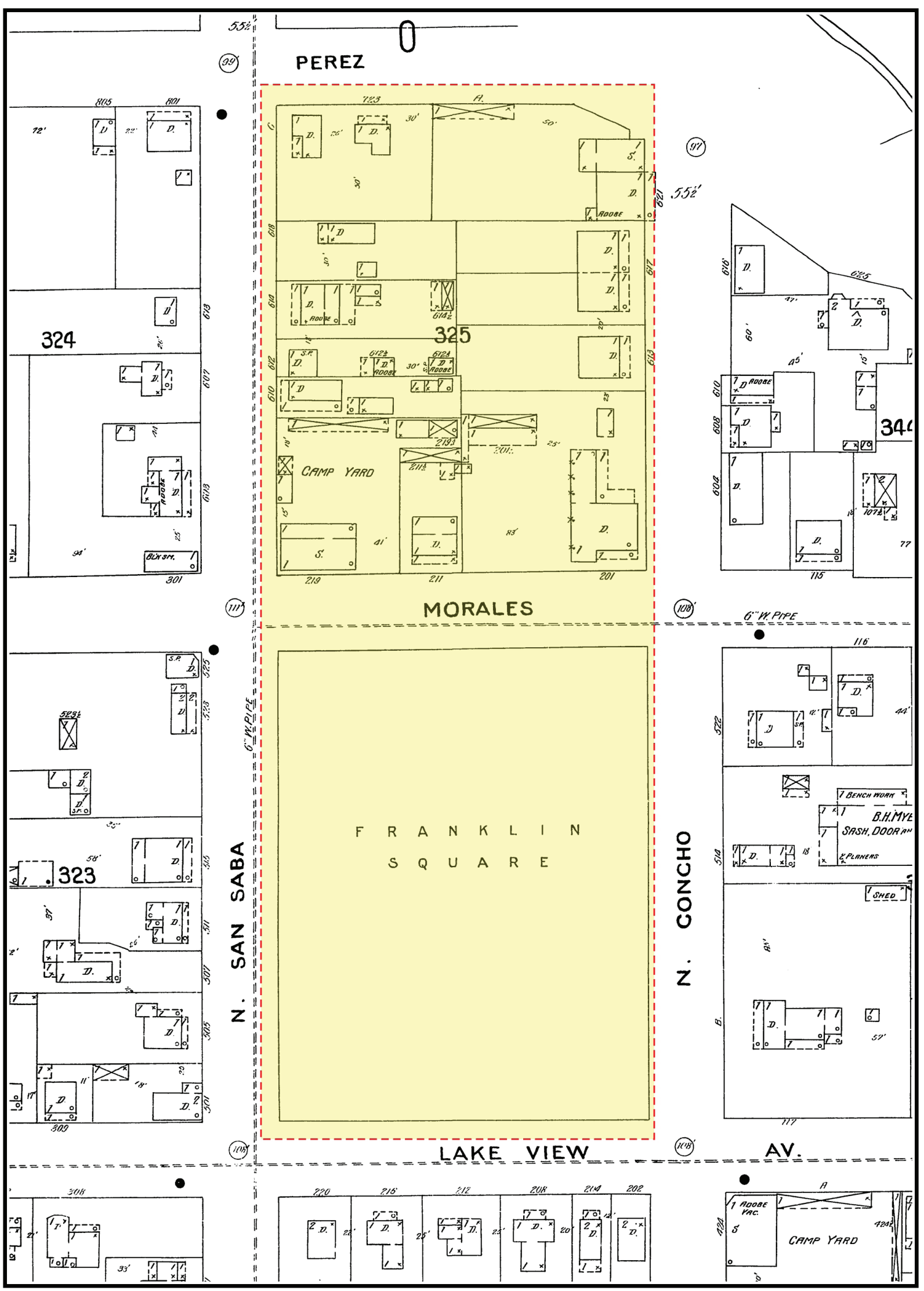

Figure 2-2. The 1896 Sanborn Map depicting the project area. 


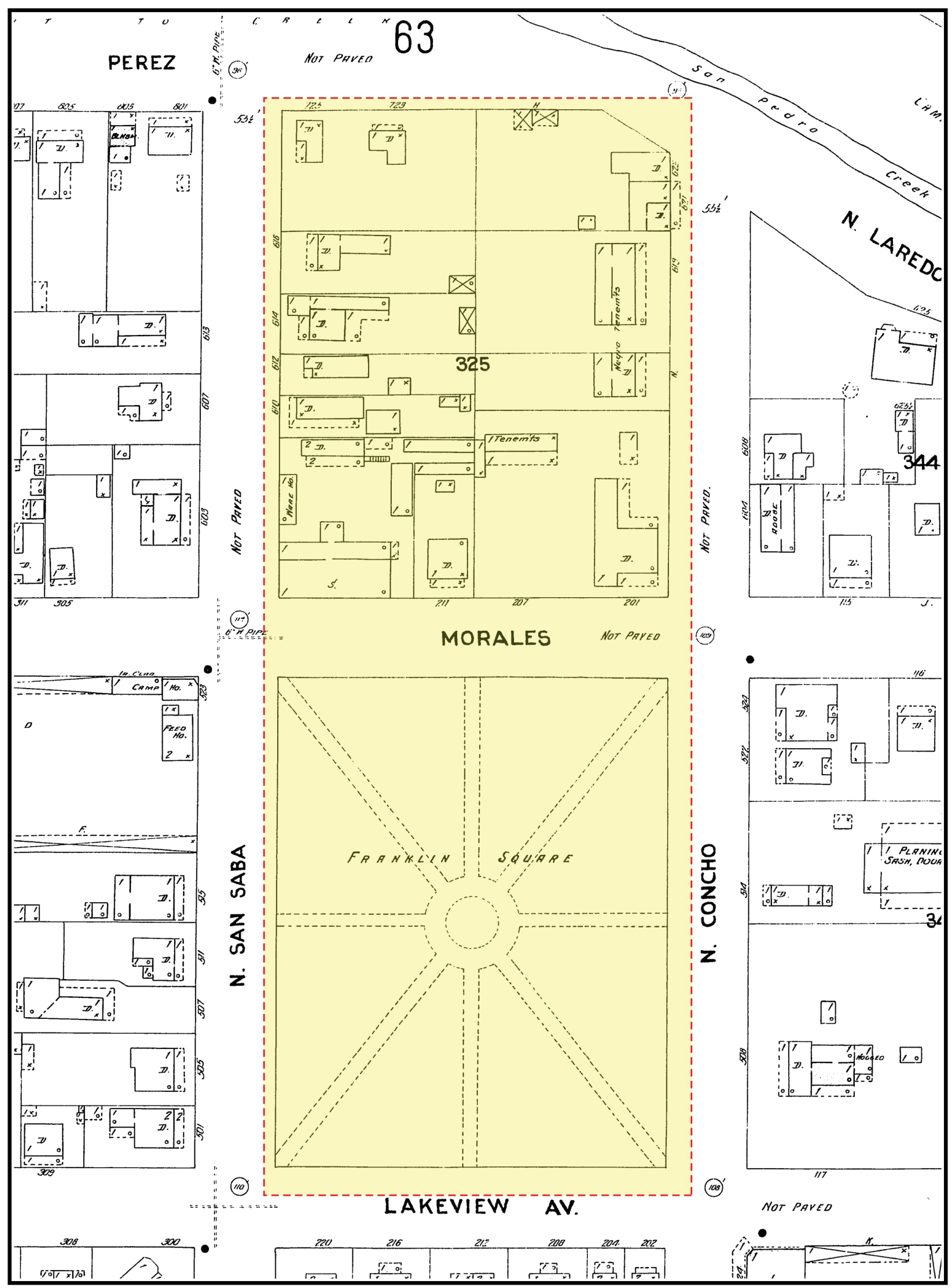

Figure 2-3. The 1904 Sanborn Map showing the project area. 
present on the property in 1911 . This map series dates prior to the construction of the church and Italian Hall.

By 1950, the church and hall had been constructed (Sanborn 1911-1950 Vol. 1, Sheet 26; Figure 2-5). The 1911-1950 Sanborn Fire Insurance Map depicts the project area as a residential area. Dwellings are present to the north and west of the church. In addition, the park is still labeled as Franklin Square. A portion of N. Concho Street was renamed N. Columbus Street by 1950 .

In March 1963, the Rosa Verde Urban Renewal Project was in the planning stage, and officials were ready to survey the area to be affected (Figure 2-6). Ordinance 31193 was approved and passed allowing the City of San Antonio to submit the request for an advance in Federal funds (SAMA 2013b). In 1967, a portion of Columbus Park was deeded to the Renewal Agency to use for construction of IH-35. The project progressed, but the Christopher Columbus Italian Society found that portions of San Saba Street and Morales Street were to be closed, impacting access to the church and hall as well as available parking in the area. As part of the solution, the Urban Renewal Project deeded a parcel of land that could be used for additional parking to the Christopher Columbus Italian Society (City Council Meeting Minutes [CCMM] Feb. 25, 1971). In the meantime, all the structures that had been located in Block 325, other than the church and the hall, were razed in preparation for the development of the area and construction of IH-35.

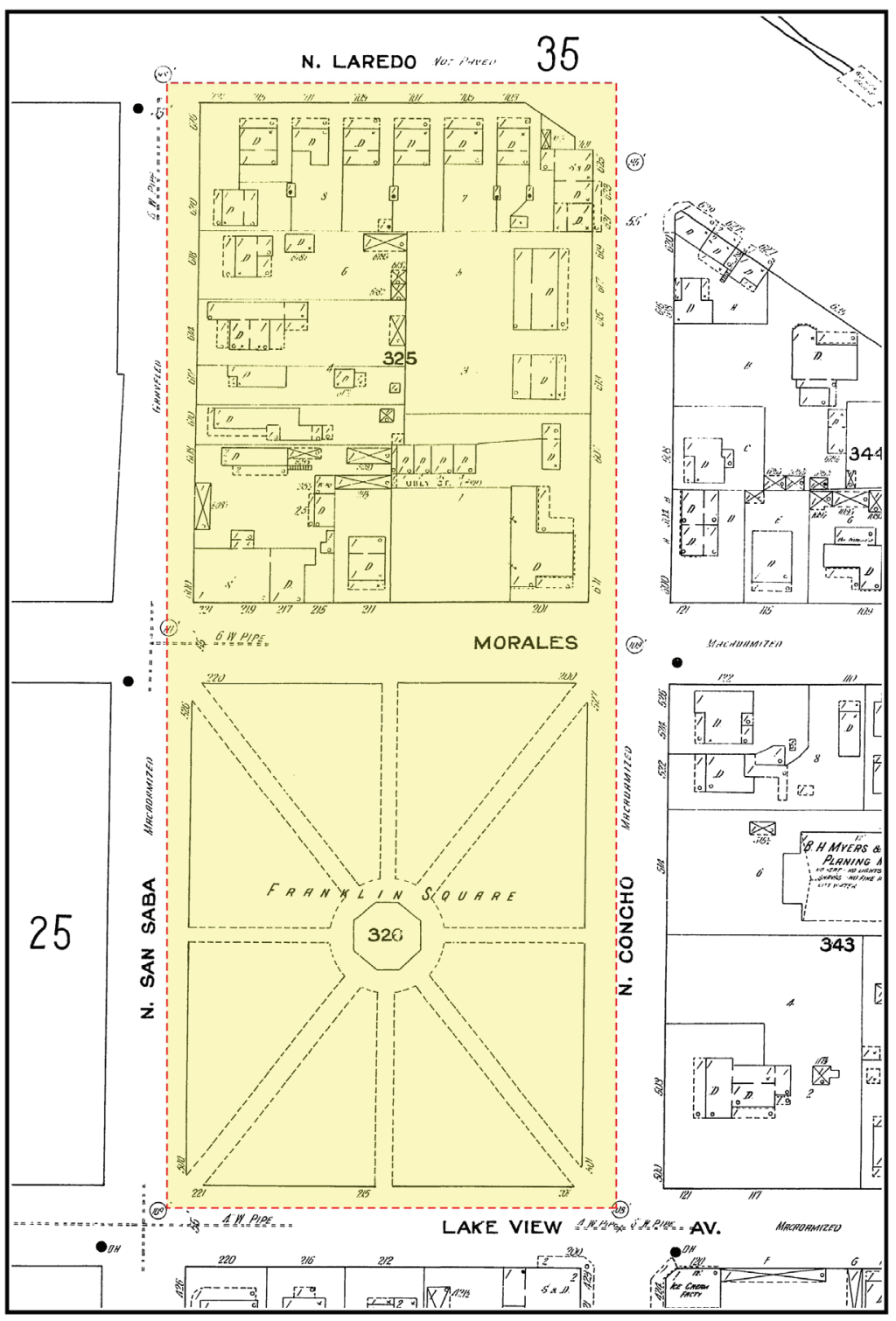

Figure 2-4. The project area in 1911 on the Sanborn Fire Insurance Map. 


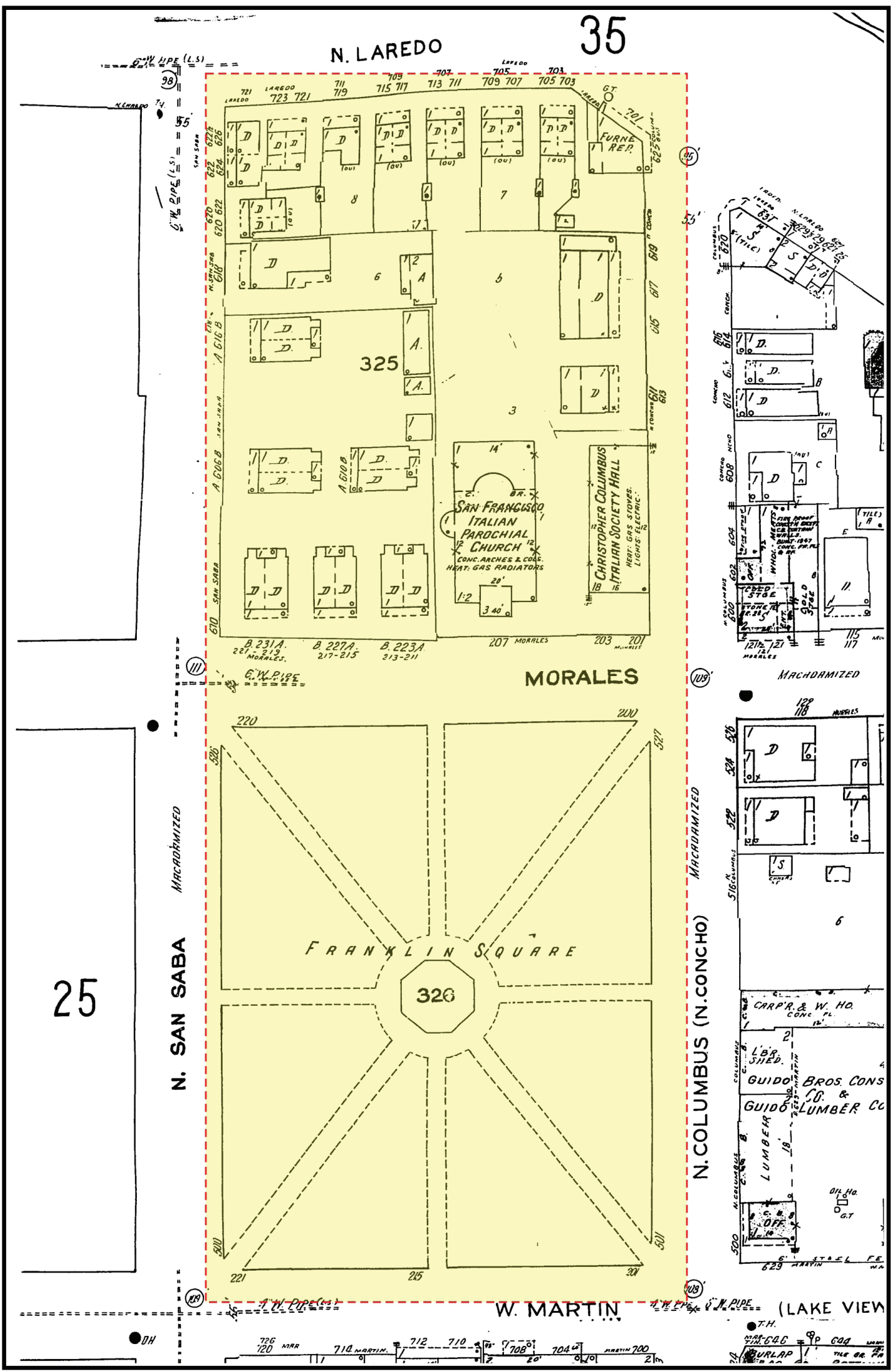

Figure 2-5. The 1911-1950 Sanborn Map depicting the project area showing the constructed church. 


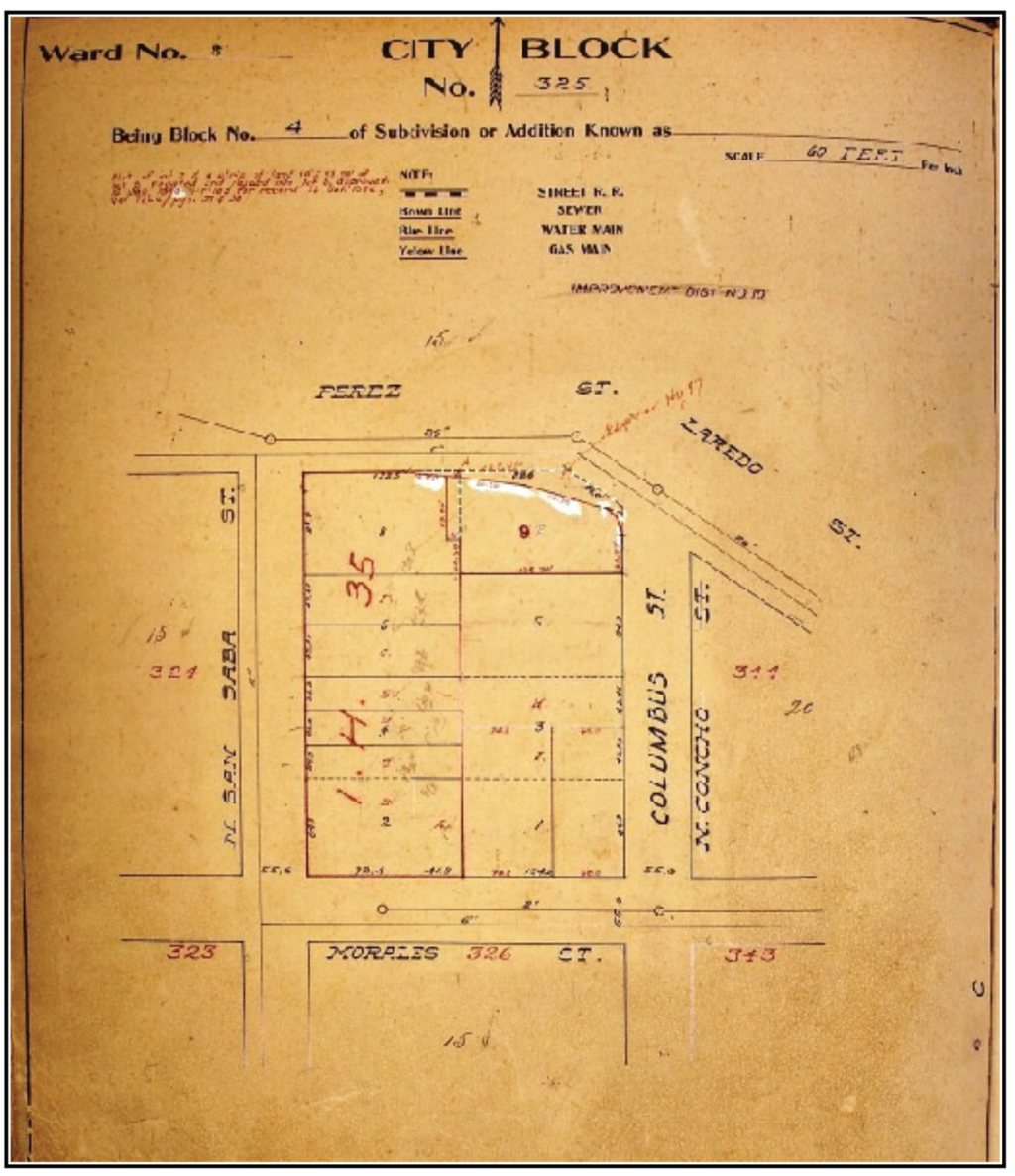

Figure 2-6. Plat showing the planning of IH-35 as part of the Urban Renewal Project.

\section{Previous Archaeology}

The project area was part of a 1979 survey conducted by CAR personnel (TASA 2013), though no archaeological sites were recorded in the vicinity of the church or hall. Three previously recorded sites are near the project area: 41BX508, 41BX514, and 41BX992.

Site 41BX508 is located approximately $0.3 \mathrm{~km}(0.2 \mathrm{mi}$.) to the southeast of the current project area. The site is listed as the Menger Soap Works and was recorded by Fox during a survey in 1979 (TASA 2013). The Soap Works was in existence during the mid-nineteenth century to the mid-twentieth century. The structure fell to ruins and was later converted into a clubhouse for an apartment complex (TASA 2013).

Located approximately $0.6 \mathrm{~km}(0.4 \mathrm{mi}$.) to the northwest of the current project area is site 41BX514, the Ximenes Chapel. The chapel is also known as the Chapel of the Miracles and was likely constructed during the 1850 s or 1860 s by Juan Ximenes, a soldier in the Texas Army who had fought in the Storming of Bexar. The chapel is listed on the National
Register of Historic Places. The chapel has been altered from its original construction but retains its cultural significance. Within the chapel is a crucifix that is believed to have been removed from Mission San Antonio de Valero. It is possible that the crucifix was entrusted to the Ximenes family once the mission was secularized. The chapel stands on private property but is open to the public (TASA 2013).

Site 41BX992, Milam Square, is located approximately $0.6 \mathrm{~km}(0.4 \mathrm{mi}$. $)$ to the south of the current project area. The area was used as a cemetery until 1885 . Although the information in the archives is scant, some documentation indicates that the burials were removed to the City Cemetery after 1885 . The property was then used as a City Park. In 1993, the CAR removed a burial that was believed to be Ben Milam (TASA 2013).

The project area falls within the boundaries of a neighborhood survey conducted in 1981 (TASA 2013). Several houses were recorded along Kingsbury Street, which is located to the east of the project area. Immediately to the east of the project area is the Towne Center Apartments that also were recorded during the 1981 survey. 


\section{Chapter 3: Field and Laboratory Methodology}

\section{Shovel Testing}

The majority of the shovel testing was conducted within Columbus Park. The scope of work called for approximately 20-40 shovel tests (STs) to be excavated within the park boundaries. After the park had been investigated, CAR personnel determined that locations for a few shovel tests would be in the open field and behind the church on property that was owned by the Christopher Columbus Italian Society. All shovel tests were $30 \mathrm{~cm}$ in diameter and most were excavated to a depth of $60 \mathrm{~cm}$ below the surface (cmbs) within Columbus Park and property owned by the Christopher Columbus Italian Society. Shovel tests were excavated in $10-\mathrm{cm}$ increments and screened through $1 / 4$-inch hardware cloth. All artifacts recovered from shovel tests were collected in bags labeled with provenience information for laboratory processing, analysis, and curation. A shovel test form was completed for every excavated shovel test. Data collected on these forms included the final excavation depth, a tally of all materials recovered from each $10-\mathrm{cm}$ level, and a brief soil description (texture, consistence, Munsell color, and inclusions). The location of every shovel test was recorded with a Magellan GPS unit. Any additional observations considered pertinent were included as comments on the standard shovel test excavation form.

\section{Test Unit Excavation}

Three test units (TUs) were excavated in arbitrary $10-\mathrm{cm}$ increments. All matrix was screened through $1 / 4$-inch hardware cloth, and all artifacts recovered from each level were bagged with the appropriate provenience information and returned to the CAR laboratory for processing and analysis. Soil samples, measuring approximately 1 -gallon each, were collected from each excavation level and returned to the laboratory where they were either dry-screened through window-screen mesh or water screened. Level forms were completed for each excavation level. Information related to the broad range of artifact types recovered, artifact quantities, and matrix type was noted on the excavation forms. All photographs taken also were noted on the form.

\section{Laboratory Procedures}

All diagnostic cultural materials obtained and records generated during the project were prepared for curation in accordance with federal regulation 36 CFR part 79 and THC requirements for State Held-in-Trust collections. Additionally, the materials have been curated in accordance with current guidelines of the CAR. The diagnostic materials collected and processed in the CAR laboratory were washed, airdried, and stored in 4-mil, zip-locking, archival-quality bags. After analysis, information concerning the artifacts collected over the course of the project was entered into an Excel ${ }^{\circledR}$ database. Acid-free labels were placed in all artifact bags. Each laser-printed label contains provenience information and a corresponding lot number. Artifacts were separated by class and stored in acid-free boxes identified with standard tags. Field notes, forms, photographs, and drawings were placed in labeled archival folders. Digital photographs were printed on acid-free paper, labeled with archival-appropriate materials, and placed in archival-quality sleeves. All field forms were completed with pencil. Any soiled forms were placed in archival-quality page protectors. Ink-jet produced maps and illustrations were also placed in archival-quality page protectors to prevent against accidental smearing. All collected materials and project related documentation that was collected from Columbus Park is permanently housed at the CAR. All material collected from the investigations conducted on the Society's property was returned to the Christopher Columbus Italian Society after the completion of the project. 



\section{Chapter 4: Results of Archaeological Investigations}

The archaeological investigations were divided between two tracts of land adjacent to the San Francesco di Paola Catholic Church. One tract consisted of Christopher Columbus Park. The other was an open field owned by the Christopher Columbus Italian Society and located behind San Francesco di Paola Church.

\section{Columbus Park}

A total of 20 shovel tests were excavated within Christopher Columbus Park (Figure 4-1). These shovel tests were placed in the grassy areas of the park, away from sprinklers and other visible utilities. The shovel tests were concentrated in

Restricted Image

Figure 4-1. Location of shovel test and test units excavated within the project area. Red circles indicate shovel tests within Columbus Park. White circles indicate shovel tests on property owned by the Christopher Columbus Society. Shovel Test 20 was not excavated. 
areas that were at a slightly higher elevation than the park's cemented pavilions and walkways. The edge of the park sloped down towards San Saba Street and Martin Street. Of the 20 shovel tests, eleven (55 percent) contained cultural material (Table 4-1). The material encountered did not date to the Spanish Colonial Period. Rather, the majority of the material was likely modern (manufactured after 1950), with a few ceramics that date to the early twentieth century.

Due to the lack of colonial or historic material, no additional shovel tests were excavated within the bounds of Columbus Park. The soil that was encountered in the shovel tests was a rich, clay loam in the upper layer that most likely was brought in during the landscaping of the park.

The second area investigated was a tract of land located to the northwest of the church building. The land is owned by the Christopher Columbus Italian Society, and there are plans to develop it in the future. The scope of work called for up to three test units to be excavated in this area. Two 1-x-1-m units (TUs 1 and 2) were placed in locations that exhibited a rock alignment on the surface. One 1-x-0.5-m unit (TU 3) was placed near TU 1 to gather more information related to the stone alignment.

\section{Test Unit 1}

Test Unit 1 was located in the vicinity of an apparent alignment of stones at the upper edge of the grassy tract (Figure 4-2). The unit included the area that exhibited reddish yellow, burned soil (Figure 4-2).

Overall, the soil encountered within the unit was compacted, light tan, and sandy. Test Unit 1 was excavated to a terminal depth of $90 \mathrm{~cm}$ below the datum ( $\mathrm{cmbd}$ ) or $65 \mathrm{cmbs}$, the end of the first sterile excavation level (Figure 4-3). A large quantity of modern glass, mostly brown or clear, was present on the surface of the unit. Other artifacts present on the surface, such as purple glass (manufacture date range 1880-1914), appear to be somewhat older (Kendrick 1966). All artifacts encountered on the surface were kept separate from the artifacts that were found within the matrix of Feature 1 (Level 1).

Ceramics encountered throughout the unit consisted of nineteenth- and twentieth-century wares. Handpainted, Sponge, and Undecorated White Earthenwares comprised the majority of the sherds encountered. The highest density of ceramics was recovered from Level $2(30-40 \mathrm{cmbd})$. One fragment of Galera ware was recovered from Level 3 (40$50 \mathrm{cmbd}$ ). Galera ware is considered a Spanish Colonial ceramic type. The vessels are orange pasted with a thin, clear glaze on the exterior. Designs are present on the exterior in cream, green, and brown colors. Common vessel forms included chocolateras, bean pots, serving dishes, plates, bowls, and cups (Fox and Ulrich 2008). The archaeological record indicates that Galera was manufactured for colonial sites occupied between 1725 and 1850. It is possible that the tradition continued for a lot longer, as similar wares are manufactured and found in Mexico today. The original manufacture of Galera occurred in Jalisco, Mexico, probably in a small town known as Tlaquepaque, near Guadalajara (Fox and Ulrich 2008).

The highest density of artifacts was recovered from the surface and upper two levels, including Feature 1, had (Table 4-2). Lower levels showed a reduction in density with the last level (70-80 cmbd) producing only a small quantity of debitage.

Table 4-1. Shovel Tests Excavated in Columbus Park

\begin{tabular}{|c|c|c|}
\hline ST & Terminal Depth (cm) & Artifact \\
\hline 1 & 60 & glass (Lev. 1) \\
\hline 2 & 60 & metal (Lev. 1), chipped stone (Lev. 2, 3) \\
\hline 3 & 60 & bone (Lev. 1) \\
\hline 4 & 60 & burned rock (Lev. 2) \\
\hline 8 & 60 & geramic/glass (Lev. 1), glass (Lev. 4) \\
\hline 10 & 60 & glass/metal (Lev. 2), brick (Lev. 6) \\
\hline 13 & 60 & glass (Lev. 3), metal (Lev. 5) \\
\hline 14 & 60 & bone/metal (Lev. 3) \\
\hline 15 & 60 & metal (Lev. 3) \\
\hline 16 & 60 & glass (Lev. 2), brick/tile (Lev. 4, 5, 6) \\
\hline 18 & 60 &
\end{tabular}




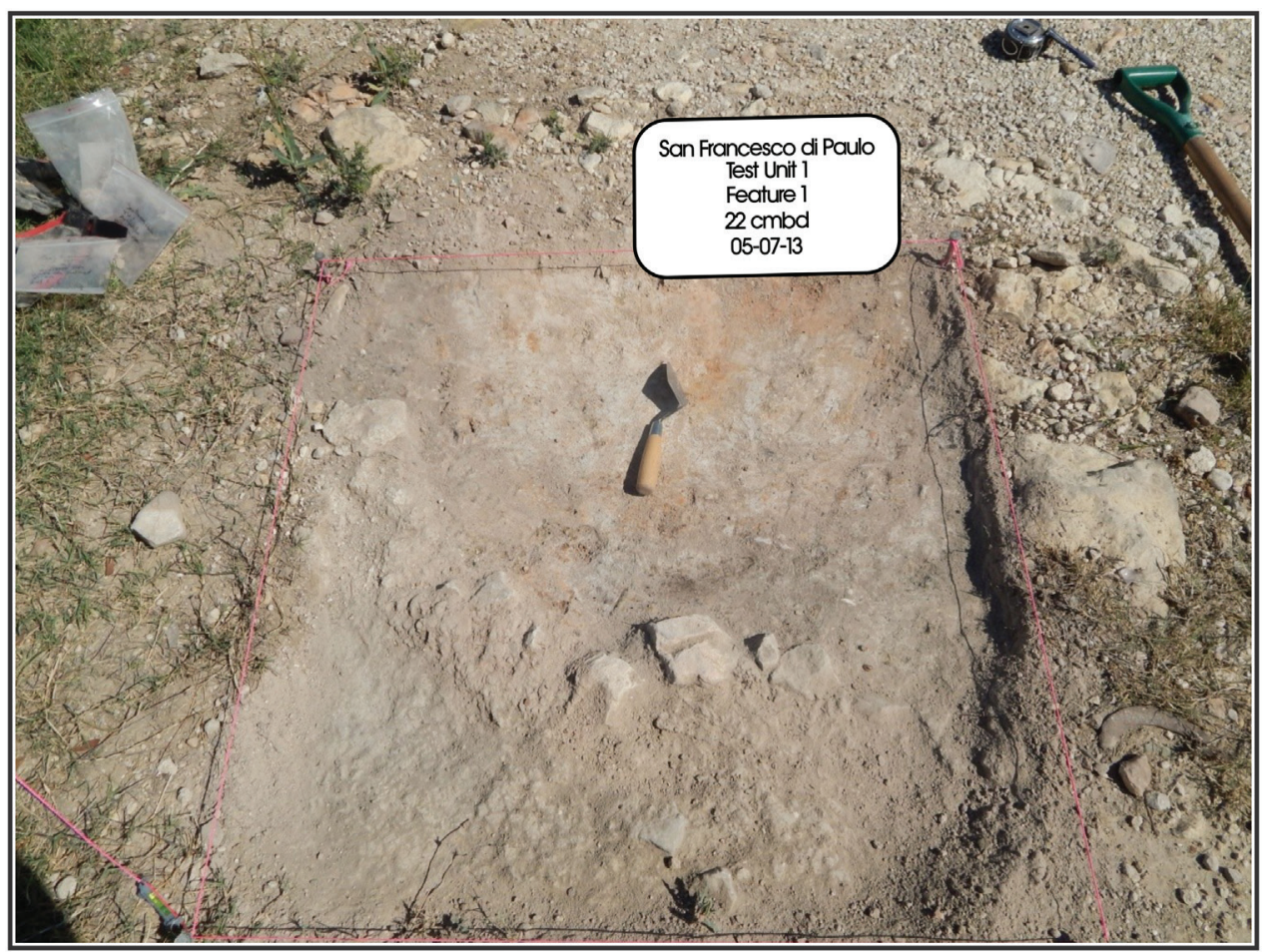

Figure 4-2. Rock alignment and burned soil in Test Unit 1.

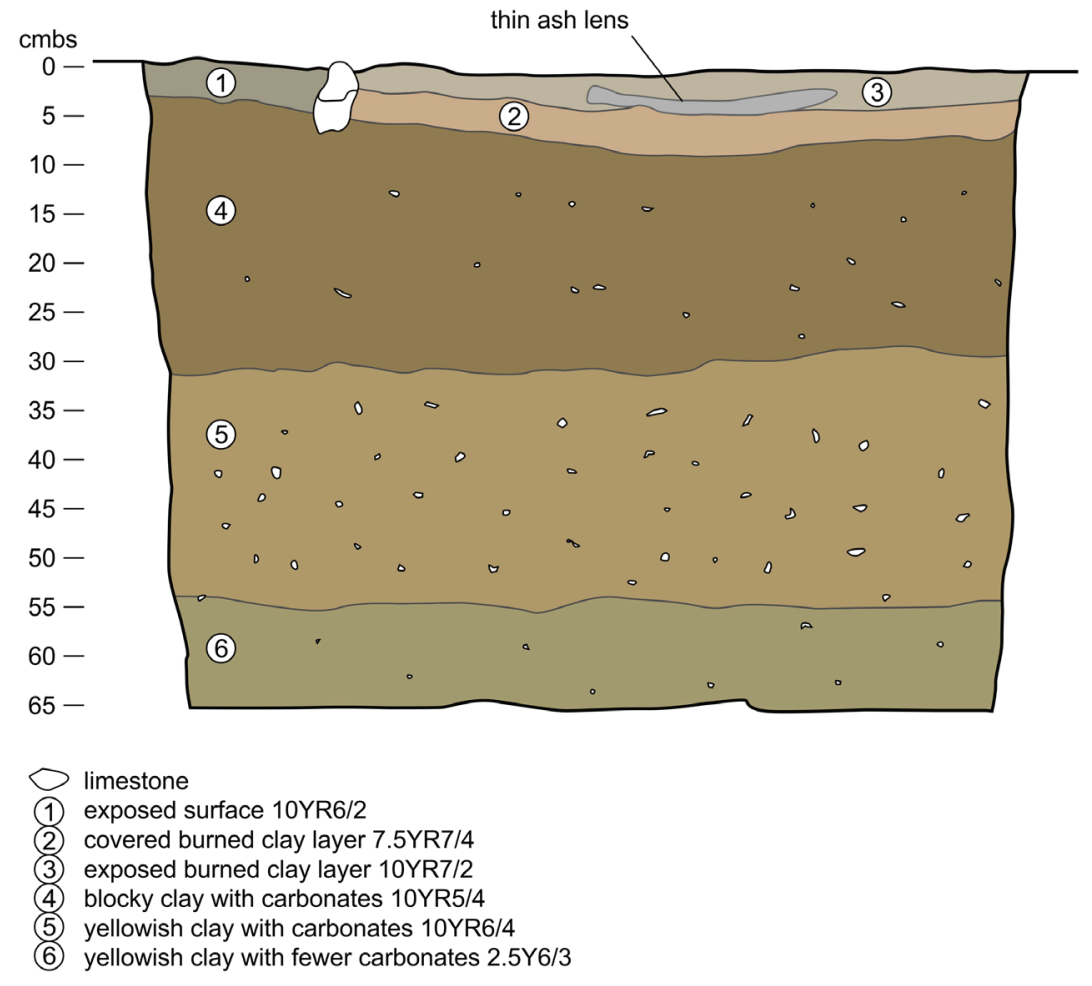

Figure 4-3. Profile of the north wall of Test Unit 1. Feature 1 consists of the ash lens and Strata 2. 
Table 4-2. Artifacts Recovered from Test Unit 1 (Note 1)

\begin{tabular}{|c|c|c|c|c|c|c|c|c|c|}
\hline Artifacts - Count & Surface & \begin{tabular}{|c|} 
Lev. 1 \\
$(20-30$ cmbd $)$
\end{tabular} & $\begin{array}{c}\text { Lev. } 2 \\
(30-40 \text { cmbd })\end{array}$ & $\begin{array}{c}\text { Lev. } 3 \\
(40-50 \mathrm{cmbd})\end{array}$ & $\begin{array}{c}\text { Lev. } 4 \\
(50-60 \mathrm{cmbd})\end{array}$ & $\begin{array}{c}\text { Lev. } 5 \\
(60-70 \mathrm{cmbd})\end{array}$ & $\begin{array}{c}\text { Lev. } 6 \\
(70-80 \mathrm{cmbd})\end{array}$ & $\begin{array}{c}\text { Lev. } 7 \\
(80-90 \text { cmbd })\end{array}$ & $\begin{array}{r}\text { Total } \\
\text { Count }\end{array}$ \\
\hline Debitage & 2 & & 4 & 2 & & 5 & 1 & & 14 \\
\hline \multicolumn{10}{|l|}{ European Ceramics } \\
\hline Stoneware - Bristol Glaze & 4 & \multirow{5}{*}{$\begin{array}{l}\text { Feature } 1 \\
\text { (Table 4-5) }\end{array}$} & & & & & & & 4 \\
\hline White Earthenware Handpainted & & & 1 & & & & & & 1 \\
\hline $\begin{array}{l}\text { White Earthenware - Sponge/ } \\
\text { Spatter }\end{array}$ & & & 1 & & & & & & 1 \\
\hline White Earthenware Undecorated & 1 & & 5 & 1 & & & & & 7 \\
\hline European Ceramics Total & 5 & & 7 & 1 & & & & & 13 \\
\hline \multicolumn{10}{|l|}{ Glass } \\
\hline Chimney - Clear & & \multirow{9}{*}{$\begin{array}{l}\text { Feature } 1 \\
\text { (Table 4-5) }\end{array}$} & 2 & & & & & & 2 \\
\hline Container/Vessel - Brown & 27 & & & & & & & & 27 \\
\hline Container/Vessel - Clear & 13 & & & & & & & & 13 \\
\hline Container/Vessel - Green & 6 & & & & & & & & 6 \\
\hline Container/Vessel - Purple & 5 & & & & & & & & 5 \\
\hline Flat - Brown & 1 & & & & & & & & 1 \\
\hline Flat - Clear & 4 & & 1 & & & & & & 5 \\
\hline Flat - Selenium & 1 & & & & & & & & 1 \\
\hline Glass Total & 57 & & 3 & & & & & & 60 \\
\hline $\begin{array}{l}\text { Personal Items - Fasteners/ } \\
\text { Button }\end{array}$ & 1 & & 3 & & & & & & 4 \\
\hline Spanish Colonial - Galera & & & & 1 & & & & & 1 \\
\hline Total Count & 65 & & 17 & 4 & & 5 & 1 & & 92 \\
\hline
\end{tabular}

\begin{tabular}{|c|c|c|c|c|c|c|c|c|c|}
\hline Artifacts - Weight (g) & Surface & $\begin{array}{c}\text { Lev. } 1 \\
(20-30 \text { cmbd) }\end{array}$ & $\begin{array}{c}\text { Lev. } 2 \\
(30-40 \text { cmbd })\end{array}$ & $\begin{array}{c}\text { Lev. } 3 \\
(40-50 \text { cmbd) }\end{array}$ & $\begin{array}{c}\text { Lev. } 4 \\
(50-60 \text { cmbd) }\end{array}$ & \begin{tabular}{|c|} 
Lev. 5 \\
$(60-70$ cmbd)
\end{tabular} & $\begin{array}{c}\text { Lev. } 6 \\
(70-80 \text { cmbd })\end{array}$ & $\begin{array}{c}\text { Lev. } 7 \\
(80-90 \text { cmbd) }\end{array}$ & $\begin{array}{l}\text { Total Wt } \\
\text { (g) }\end{array}$ \\
\hline Building Materials & & & 405.66 & & & & & & 405.66 \\
\hline \multicolumn{10}{|l|}{ Metal } \\
\hline Cut Nails & & \multirow{6}{*}{$\begin{array}{l}\text { Feature 1 } \\
\text { (Table 4-5) }\end{array}$} & 28.18 & 1.87 & & 3.79 & & & 33.84 \\
\hline Farm/Ranch/Tack related & 0.62 & & & & & & & & 0.62 \\
\hline Other - Cuprous & & & 8.06 & & & & & & 8.06 \\
\hline Other - Ferrous Scrap & & & 187.75 & & & & & & 187.75 \\
\hline Wire Nails & 0.45 & & & & & & & & 0.45 \\
\hline Metal Total & 1.07 & & 223.99 & 1.87 & & 3.79 & & & 230.72 \\
\hline Organics - Bone & 1.15 & & 26.23 & 0.98 & & & & & 28.36 \\
\hline \multicolumn{10}{|l|}{ Samples } \\
\hline Burned Rock & & \multirow{3}{*}{$\begin{array}{l}\text { Feature } 1 \\
\text { (Table 4-5) }\end{array}$} & 66.24 & & 3.2 & 3.92 & & & 73.36 \\
\hline Other & & & 45.54 & & & & & & 45.54 \\
\hline Samples Total & & & 111.78 & & 3.2 & 3.92 & & & 118.9 \\
\hline Total Weight (g) & 2.22 & & 767.66 & 2.85 & 3.2 & 7.71 & & & 783.64 \\
\hline
\end{tabular}




\section{Test Unit 2}

Test Unit 2 was placed adjacent to another rock alignment that was noticed to the north of TU 1 (Figure 4-4). The unit was placed at the edge of the alignment to determine if there was another course of stones below the surface. Level 7 was excavated to a terminal depth of $90 \mathrm{cmbd}$, and it was excavated only in the southern half of the unit. Over 600 artifacts were recovered from Levels 1-6 (Table 4-3). Level 7 was sterile and was not included on the table.

A concentration of stones was encountered in the southeast corner in the first level. Excavation revealed that the stone alignment noted on the surface was only one course thick. Artifacts encountered in Level 1 (20-30 cmbd) consisted of glass and metal fragments, animal bone, burned rock, and a heavily rusted pocketknife (Table 4-3). A garment slider strap was also collected from the unit. The glass fragments consisted mainly of aqua, brown, or clear pieces. A few fragments of olive glass were encountered in the unit. During the Spanish Colonial Period, wine that was used at the missions would have been stored in olive-colored glass bottles. These would have been hand-blown and would have exhibited uneven walls and pontil marks on the bases. No bases with pontil marks were recovered from the site during this project, but many of the fragments exhibited a patina that indicated that some pieces likely predated the twentieth century (Lindsey 2013).

The typical vessel type encountered at the missions is a wine bottle. Olive green glass was not commonly used in water or soda bottles after 1870 or for other vessel types after the 1860 s. Wine and champagne bottles are still manufactured with olive glass, but these often have a brighter hue (Lindsey 2013). In addition to olive glass, dark olive glass was also recovered. Dark olive is sometimes referred to as "Black Glass" because the olive tint is so dark that the glass is practically opaque. Dark olive glass is believed to be one of the earliest glass types found at North American sites. The use of dark olive glass began in the seventeenth century in Europe (Lindsey 2013). American-made dark olive glass became more uncommon after 1880, and the European-made glass was uncommon by the 1890s. Dark olive glass vessels were typically made for alcohol, wine, and, occasionally, mineral water. One fragment of dark olive glass was recovered in Level 4.

The upper four levels of excavation produced the highest density of artifacts. The manufacture age of the artifacts appeared to range from the mid-nineteenth to the midtwentieth century. A small number of ceramics that were manufactured during Spanish Colonial Period were encountered (Puebla Blue on White majolica and a Galera

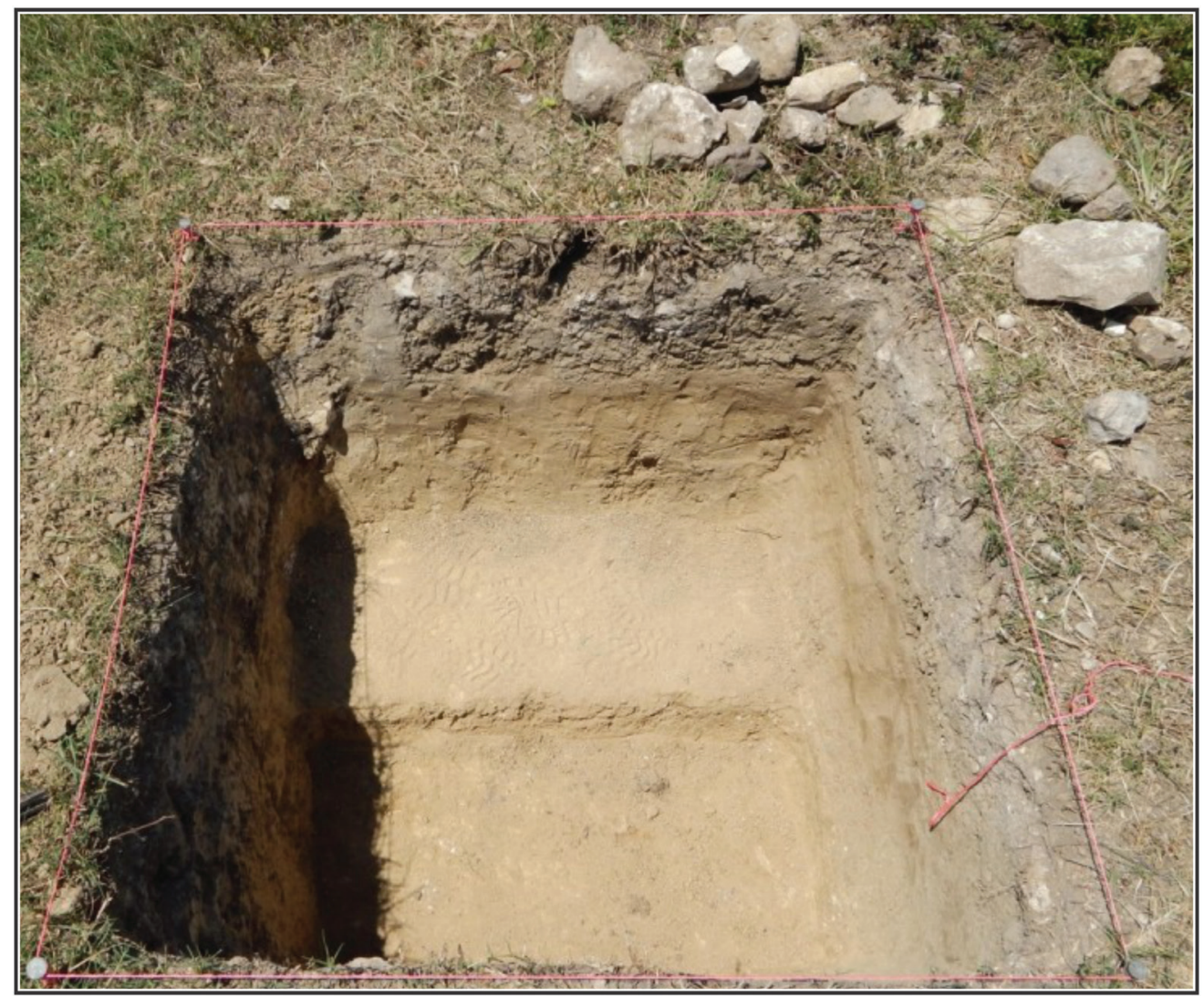

Figure 4-4. Test Unit 2 looking north. Note that the last level (Lev. 7) was excavated only in the southern half of the unit. 
Table 4-3. Artifacts Recovered from Test Unit 2

\begin{tabular}{|c|c|c|c|c|c|c|c|}
\hline Artifacts - Count & $\begin{array}{c}\text { Lev. } 1 \\
(20-30 \text { cmbd) } \\
\end{array}$ & $\begin{array}{c}\text { Lev. } 2 \\
(30-40 \text { cmbd) }\end{array}$ & $\begin{array}{c}\text { Lev. } 3 \\
(40-50 \text { cmbd) } \\
\end{array}$ & $\begin{array}{c}\text { Lev. } 4 \\
(50-60 \text { cmbd) } \\
\end{array}$ & $\begin{array}{c}\text { Lev. } 5 \\
\text { (60-70 cmbd) } \\
\end{array}$ & $\begin{array}{c}\text { Lev. } 6 \\
(70-80 \text { cmbd) } \\
\end{array}$ & $\begin{array}{l}\text { Total } \\
\text { Count }\end{array}$ \\
\hline Brick & & 1 & & 1 & & & 2 \\
\hline \multicolumn{8}{|l|}{ Building Materials } \\
\hline Limestone & 3 & & 1 & & & & 4 \\
\hline Mortar & & 1 & 1 & & & & 3 \\
\hline Building Materials Total & 3 & 1 & 3 & & & & 7 \\
\hline \multicolumn{8}{|l|}{ Chipped Stone } \\
\hline Core Tool & 1 & & & & & & 1 \\
\hline Debitage & 5 & 3 & 1 & & & & 9 \\
\hline Edge-Modified & & & 1 & & & & 1 \\
\hline Chipped Stone Total & 6 & 3 & 2 & & & & 11 \\
\hline $\begin{array}{l}\text { Construction Materials - } \\
\text { Asphalt }\end{array}$ & & 1 & & & & & 1 \\
\hline \multicolumn{8}{|l|}{ European Ceramics } \\
\hline Earthenware - Annular Ware & & & & & & 1 & 1 \\
\hline Handpainted & & & 1 & & & & 1 \\
\hline $\begin{array}{l}\text { Earthenware - Plain Colored } \\
\text { Glaze }\end{array}$ & 2 & 3 & 2 & & & & 7 \\
\hline Earthenware - Rim-Band & & & 1 & & & & 1 \\
\hline Earthenware -Transferware & 2 & 2 & & & & & 4 \\
\hline $\begin{array}{l}\text { Undecorated White Earth- } \\
\text { enware }\end{array}$ & 6 & 6 & 3 & & & & 15 \\
\hline Ironstone & 1 & & & & & & 1 \\
\hline Porcelain & & & 1 & & & & 1 \\
\hline Stoneware - Flower Pot & 1 & & & & & & 1 \\
\hline European Ceramics Total & 12 & 11 & 8 & & & 1 & 32 \\
\hline \multicolumn{8}{|l|}{ Glass } \\
\hline Chimney & 8 & 5 & 1 & & & & 14 \\
\hline Container/Vessel - Amber & 2 & & & & & & 2 \\
\hline Container/Vessel - Aqua & 6 & 5 & 9 & & & & 20 \\
\hline Container/Vessel - Brown & 14 & 10 & 1 & & 1 & 1 & 27 \\
\hline Container/Vessel - Clear & 31 & 19 & 8 & 11 & 1 & & 70 \\
\hline Container/Vessel - Cobalt & & & & 1 & 1 & & 2 \\
\hline $\begin{array}{l}\text { Container/Vessel - Dark } \\
\text { Olive }\end{array}$ & & & & 1 & & & 1 \\
\hline Container/Vessel - Green & 1 & 1 & & 1 & & & 3 \\
\hline Container/Vessel - Olive & 1 & & 2 & 1 & & & 4 \\
\hline Container/Vessel - Purple & 1 & 3 & & & & & 4 \\
\hline Flat - Aqua & 11 & 14 & 15 & & & & 40 \\
\hline Flat - Clear & 13 & 13 & 3 & & & 1 & 30 \\
\hline Glass Total & 88 & 70 & 39 & 15 & 3 & 2 & 217 \\
\hline Manufactured - Plastic & 2 & & & & & & 2 \\
\hline \multicolumn{8}{|l|}{ Metal } \\
\hline Cut Nail & 2 & & 10 & & & & 12 \\
\hline
\end{tabular}


Table 4-3. Artifacts Recovered from Test Unit 2, continued...

\begin{tabular}{|c|c|c|c|c|c|c|c|}
\hline Artifacts - Count & $\begin{array}{c}\text { Lev. } 1 \\
\text { (20-30 cmbd) }\end{array}$ & $\begin{array}{c}\text { Lev. } 2 \\
\text { (30-40 cmbd) }\end{array}$ & $\begin{array}{c}\text { Lev. } 3 \\
\text { (40-50 cmbd) }\end{array}$ & $\begin{array}{c}\text { Lev. } 4 \\
(50-60 \text { cmbd) }\end{array}$ & $\begin{array}{c}\text { Lev. } 5 \\
\text { (60-70 cmbd) }\end{array}$ & $\begin{array}{c}\text { Lev. } 6 \\
\text { (70-80 cmbd) }\end{array}$ & $\begin{array}{l}\text { Total } \\
\text { Count }\end{array}$ \\
\hline Screw & 1 & & & & & & 1 \\
\hline Bottle Cap & & & 1 & & & & 1 \\
\hline Cast-Iron & 3 & & & & & & 3 \\
\hline Foil & & 1 & & & & & 1 \\
\hline Scrap & 18 & 93 & 58 & 93 & & & 262 \\
\hline Seal & & 1 & & & & & 1 \\
\hline Wire Nail & & & 5 & & & & 5 \\
\hline Metal Total & 24 & 95 & 74 & 93 & & & 286 \\
\hline \multicolumn{8}{|l|}{ Organics } \\
\hline Bone & 1 & 3 & 3 & 2 & & & 9 \\
\hline Mussel Shell & & 1 & 1 & & & & 2 \\
\hline Organics Total & 1 & 4 & 4 & 2 & & & 11 \\
\hline \multicolumn{8}{|l|}{ Personal Items } \\
\hline Slide Strap & & 1 & & & & & 1 \\
\hline Pocketknife & 1 & & & & & & 1 \\
\hline Glass Marble & & & 1 & & & & 1 \\
\hline Personal Items Total & 1 & 1 & 1 & & & & 3 \\
\hline \multicolumn{8}{|l|}{ Samples } \\
\hline Burned Rock & 7 & 13 & & & & & 20 \\
\hline Charcoal & & 1 & 1 & 1 & & & 3 \\
\hline Samples Total & 7 & 14 & 1 & 1 & & & 23 \\
\hline \multicolumn{8}{|l|}{ Spanish Colonial } \\
\hline Lead Glazed - Galera & 1 & 1 & & 1 & & & 3 \\
\hline Yellow Lead Glazed & & 5 & & & & & 5 \\
\hline $\begin{array}{l}\text { Tin Glazed - Puebla Blue on } \\
\text { White }\end{array}$ & & & 1 & & & & 1 \\
\hline Spanish Colonial Total & 1 & 6 & 1 & 1 & & & 9 \\
\hline Total Count & 145 & 207 & 133 & 113 & 3 & 3 & 604 \\
\hline
\end{tabular}

\begin{tabular}{|c|c|c|c|c|c|c|c|}
\hline Artifacts - Weight (g) & $\begin{array}{c}\text { Lev. } 1 \\
\text { (20-30 cmbd) }\end{array}$ & $\begin{array}{l}\text { Lev. } 2 \\
\text { (30-40 cmbd) }\end{array}$ & $\begin{array}{c}\text { Lev. } 3 \\
\text { (40-50 cmbd) }\end{array}$ & $\begin{array}{c}\text { Lev. } 4 \\
\text { (50-60 cmbd) }\end{array}$ & $\begin{array}{l}\text { Lev. } 5 \\
\text { (60-70 cmbd) }\end{array}$ & $\begin{array}{c}\text { Lev. } 6 \\
\text { (70-80 cmbd) }\end{array}$ & $\begin{array}{c}\text { Total } \\
\text { Weight (g) }\end{array}$ \\
\hline Brick & & 66.75 & & 1.92 & & & 68.67 \\
\hline \multicolumn{8}{|l|}{ Building Materials } \\
\hline Limestone & 620.31 & & 105.01 & & & & 725.32 \\
\hline Mortar & & 31.94 & 46.99 & & & & 78.93 \\
\hline Building Materials Total & 620.31 & 31.94 & 152 & & & & 804.25 \\
\hline $\begin{array}{l}\text { Construction Materials - } \\
\text { Asphalt }\end{array}$ & & 3.49 & & & & & 3.49 \\
\hline \multicolumn{8}{|l|}{ Metal } \\
\hline Cut Nail & 1.55 & & 29.95 & & & & 31.5 \\
\hline
\end{tabular}


Table 4-3. Artifacts Recovered from Test Unit 2 continued....

\begin{tabular}{|c|c|c|c|c|c|c|c|}
\hline Artifacts - Weight (g) & $\begin{array}{c}\text { Lev. } 1 \\
\text { (20-30 cmbd) }\end{array}$ & $\begin{array}{c}\text { Lev. } 2 \\
\text { (30-40 cmbd) }\end{array}$ & $\begin{array}{c}\text { Lev. } 3 \\
\text { (40-50 cmbd) }\end{array}$ & $\begin{array}{c}\text { Lev. } 4 \\
\text { (50-60 cmbd) }\end{array}$ & $\begin{array}{c}\text { Lev. } 5 \\
\text { (60-70 cmbd) }\end{array}$ & $\begin{array}{c}\text { Lev. } 6 \\
\text { (70-80 cmbd) }\end{array}$ & $\begin{array}{c}\text { Total } \\
\text { Weight (g) }\end{array}$ \\
\hline Screw & 3.97 & & & & & & 3.97 \\
\hline Bottle Cap & & & 0.92 & & & & 0.92 \\
\hline Cast-Iron & 65.38 & & & & & & 65.38 \\
\hline Foil & & 0.31 & & & & & 0.31 \\
\hline Scrap & 11.24 & 169.75 & 37.35 & 49.04 & & & 267.38 \\
\hline Seal & & 1.16 & & & & & 1.16 \\
\hline Wire Nail & & & 10.11 & & & & 10.11 \\
\hline Metal Total & 82.14 & 171.22 & 78.33 & 49.04 & & & 380.73 \\
\hline \multicolumn{8}{|l|}{ Organics } \\
\hline Bone & 15.05 & 22.01 & 61.51 & 5.08 & & & 103.65 \\
\hline Mussel Shell & & 3.03 & 0.53 & & & & 3.56 \\
\hline Organics Total & 15.05 & 25.04 & 62.04 & 5.08 & & & 107.21 \\
\hline \multicolumn{8}{|l|}{ Personal Items } \\
\hline Slide Strap & & 1.16 & & & & & 1.16 \\
\hline Pocketknife & 28.18 & & & & & & 28.18 \\
\hline Personal Items Total & 28.18 & 1.16 & & & & & 29.34 \\
\hline \multicolumn{8}{|l|}{ Samples } \\
\hline Burned Rock & 53.88 & 26.89 & & & & & 80.77 \\
\hline Charcoal & & 1.32 & 1.97 & 1.39 & & & 4.68 \\
\hline Samples Total & 53.88 & 28.21 & 1.97 & 1.39 & & & 85.45 \\
\hline Total Weight (g) & 799.56 & 327.81 & 294.34 & 57.43 & & & $1,479.14$ \\
\hline
\end{tabular}

Lead Glazed). However, these types span the entire Spanish Colonial Period and extend into the post-colonial era. Puebla Blue on White is one of the most common majolica traditions recovered from Spanish Colonial sites. Puebla Blue on White was manufactured throughout the eighteenth century. In Texas, Puebla Blue on White was common throughout the mission period (1718 to 1830s; Fox and Ulrich 2008). Galera ware fragments were also recovered from Levels 1, 2, and 4 (Figure 4-5). The Galera sherds were recovered in Levels 1 and 2, and the Puebla Blue on White ceramic sherds were recovered in Level 3. Levels 1-3 also contained later ceramic varieties (Table 4-3).

The later European ceramic types encountered included Annular Ware, Handpainted White Earthenware, Plain Colored Glaze, and Transferware. Annular Ware is characterized by bands of colored slip that are applied to a vessel in its leather-hard state before firing. Typically, the vessels are white-bodied, with the applied bands in brown, tan, yellow, green, black, and blue colors. In San Antonio, Annular Ware vessels can be seen throughout the nineteenth century. Mocha was popular prior to 1840 , while the other varieties gained predominance after that date (Fox et al. 1997). Typical motifs on Handpainted Earthenwares are floral designs executed in bright colors. Many of the flowers are blue, pink, and yellow with light to dark green leaves. The brush strokes are apparent on these decorations. Although dates of manufacture range throughout the nineteenth century, most would have been made after 1830 . The wares were manufactured in England (Fox et al. 1997).

In the making of Transferware, a design is printed on a piece of tissue paper and is then laid on the ceramic vessel to transfer the wet ink design. The vessel would then be fired to set the design. The most common color of transfer designs is blue, though brown, maroon, and green versions have also been seen. Transferware production in England began in the 1750 s, and the vessels were exported to the United States well 


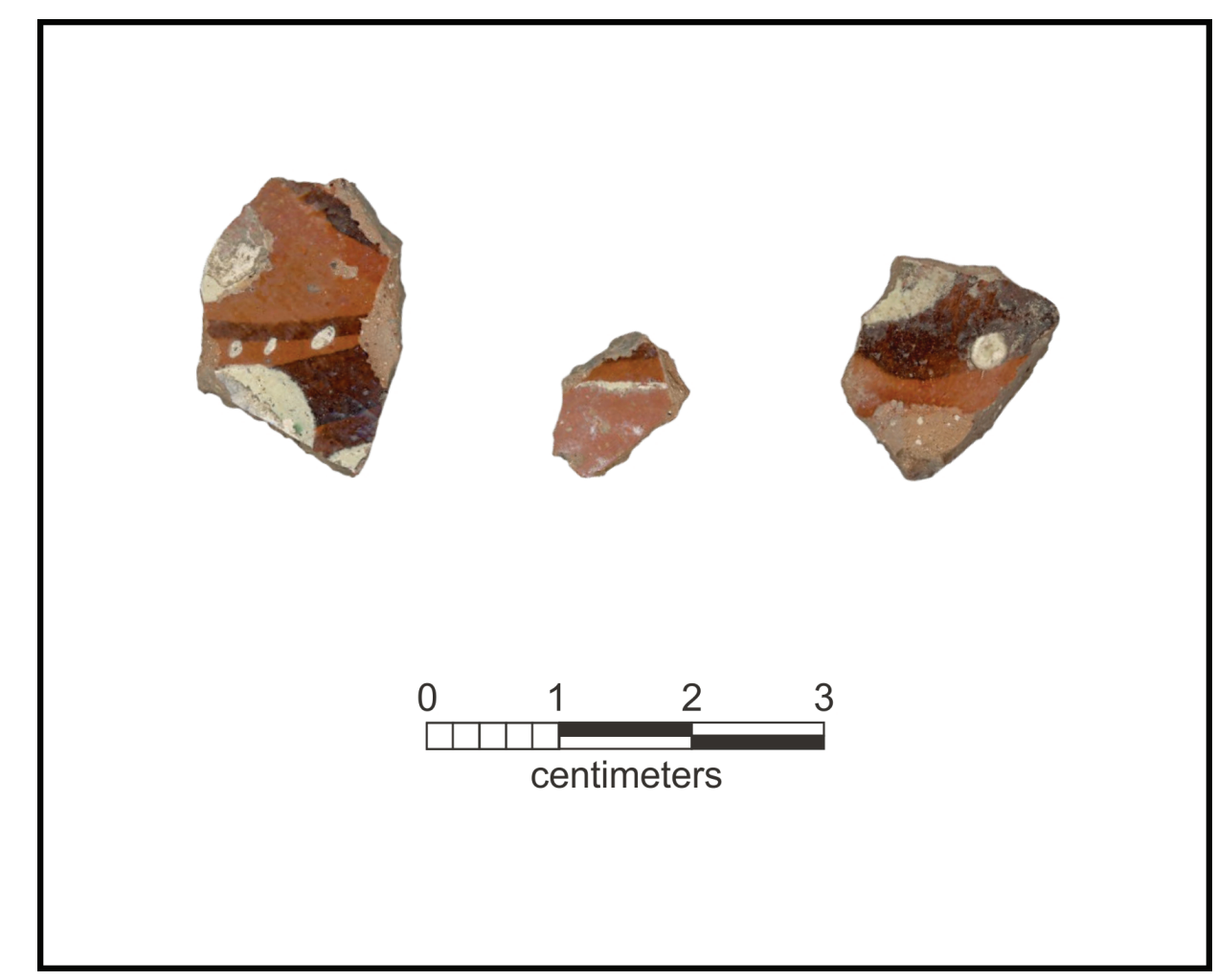

Figure 4-5. Fragments of Galera ware recovered from Test Unit 2.

into the late nineteenth century. In San Antonio, Transferware became common around the mid-eighteenth century and was even more common after the arrival of the railroad in the 1870s. Earlier vessels made their way into the area, but they would have been more expensive to acquire (Fox et al. 1997).

In Level 2, the remnants of a metal paint can were uncovered. The metal was rusted and fell apart upon excavation. The metal from the can is what comprises the majority of the "Scrap" metal category in Level 2.

The artifact density decreased in Levels 5 and 6, with Level 7 (50-x-100-cm) being sterile. A soil change was noted in Level 5 associated with an increase in the number of carbonate nodules. The unit was terminated once the excavation of the sterile level was complete in the southern half of the unit. No evidence of a structure foundation was uncovered in this unit. Though some artifacts that are associated with the Spanish Colonial Period were recovered, they were in mixed context with later material.

\section{Test Unit 3}

Test Unit 3 was a $0.5-\mathrm{x}-1-\mathrm{m}$ unit that was placed near TU 1 . Test Unit 3 was placed on the east side of the first rock alignment that was noted during the original site visit (Figure 4-6).
This partial unit was added to further explore the cluster of surface-exposed rocks that also were present in TU 1, adjacent to TU 3. The excavation of the unit was terminated at $140 \mathrm{cmbd}$. A total of 455 artifacts were collected during the excavation of TU 3. In comparison to the two 1-x-1-m units, this unit had the highest density of artifacts. Glass and metal comprised the largest classes of artifacts encountered.

The excavation of TU 3 encountered similar soils as noted in TU 1, with one exception. It would appear that TU 3 was situated over a pit. Although not prominent in the profile, the unit contained a loose area of soil with a peak in artifact density that was bordered by extremely compact soil containing fewer artifacts. As excavation proceeded, it became evident that a trash pit was encountered in Level 5. The trash pit was defined as Feature 2.

Cultural materials recovered from TU 3 not associated with Feature 2 are presented in Table 4-4. Levels 6 through 12 are associated with Feature 2, and the artifacts associated with this feature are discussed in a later section. Artifacts encountered in the unit included glass fragments of various colors. Most common was aqua, brown, or clear glass, but green and olive colors were also encountered. The demand for aqua glass may have decreased with the increased availability of clear glass after the 1880s. Aqua glass vessels are typically soda and water bottles, canning jars, and some 


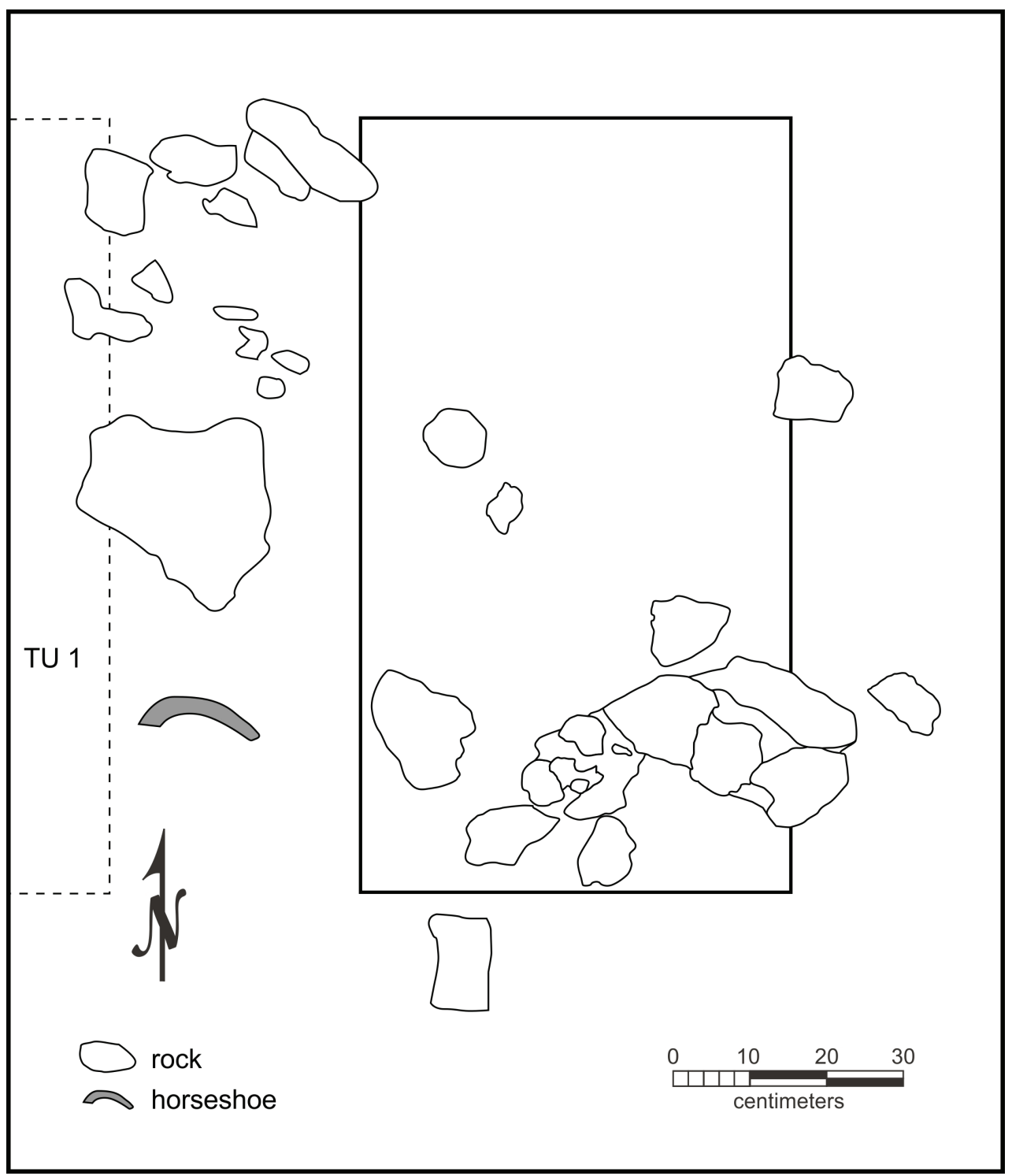

Figure 4-6. Test Unit 3 showing rocks on the surface of the 1-x-0.5-m unit.

medicine bottles. Machine-made aqua bottle glass typically pre-dates the 1920s (Lindsey 2013). This excludes canning jars and soda bottles. Coca-Cola bottles and some Dr. Pepper bottles continued to use aqua glass well into the late twentieth century. The presence of aqua glass fragments indicates glass manufactured prior to the 1930s (Lindsey 2013). Eleven sherds of aqua glass were recovered from TU 3 . The highest density $(n=5)$ came from Level 3 , though the numbers appears to remain pretty consistent with one to three fragments recovered in each level (Table 4-4).

A total of three green glass fragments were recovered. There are various shades of green glass that fall into this color group. Similar to olive glass and even brown glass, the shade often varies from glass batch to batch. The 7-Up green and Coke bottle green are shades that were developed during the twentieth century. There may be a few instances of the bright 7-Up color being found on late-nineteenth-century vessels, but it is more commonly associated with the glass used in the vibrantly colored 7-Up bottles (Lindsey 2013). The green glass fragments recovered in Level 1 were of the 7-Up variety.

As previously mentioned, olive glass is typically associated with the Spanish Colonial occupation of San Antonio. Two fragments were recovered within the upper levels of the unit, one in Level 2 and one in Level 5. 
Table 4-4. Artifacts Recovered from Test Unit 3 above Feature 2

\begin{tabular}{|c|c|c|c|c|c|c|}
\hline Artifacts - Count & $\begin{array}{c}\text { Lev. } 1 \\
(10-20 \text { cmbd })\end{array}$ & $\begin{array}{c}\text { Lev. } 2 \\
\text { (20-30 cmbd) }\end{array}$ & $\begin{array}{c}\text { Lev. } 3 \\
(30-40 \text { cmbd) }\end{array}$ & $\begin{array}{c}\text { Lev. } 4 \\
(40-50 \text { cmbd) }\end{array}$ & $\begin{array}{c}\text { Lev. } 5 \\
(50-60 \mathrm{cmbd})\end{array}$ & Total Count \\
\hline $\begin{array}{l}\text { Building Materials - } \\
\text { Mortar }\end{array}$ & 2 & & & & & 2 \\
\hline Debitage & & 3 & & 1 & 1 & 5 \\
\hline \multicolumn{7}{|l|}{ European Ceramics } \\
\hline $\begin{array}{l}\text { Undecorated White } \\
\text { Earthenware }\end{array}$ & 1 & 3 & 4 & & 1 & 9 \\
\hline Ironstone & & & & & 1 & 1 \\
\hline Unknown Lead Glazed & 5 & 1 & & & & 6 \\
\hline Porcelain & 1 & & 1 & & & 2 \\
\hline Semi-Porcelain & & & 1 & & & 1 \\
\hline $\begin{array}{l}\text { European Ceramics } \\
\text { Total }\end{array}$ & 7 & 4 & 6 & & 2 & 19 \\
\hline \multicolumn{7}{|l|}{ Glass } \\
\hline Chimney & 1 & 2 & & & & 3 \\
\hline Container/Vessel - Aqua & 3 & & 5 & 2 & 1 & 11 \\
\hline Container/Vessel - Brown & 6 & & 3 & & & 9 \\
\hline Container/Vessel - Clear & 9 & 16 & & 1 & & 26 \\
\hline Container/Vessel - Green & 3 & & & & & 3 \\
\hline Container/Vessel - Olive & & 1 & & & 1 & 2 \\
\hline Flat - Aqua & 9 & 3 & 3 & & & 15 \\
\hline Flat - Clear & 14 & 1 & & & & 15 \\
\hline Glass Total & 45 & 23 & 11 & 3 & 2 & 84 \\
\hline Manufactured - Rubber & 1 & & & & & 1 \\
\hline \multicolumn{7}{|l|}{ Metal } \\
\hline Arms - Shotgun Shell & & 1 & & & & 1 \\
\hline Cut Nails & 1 & 7 & 1 & 1 & 9 & 19 \\
\hline Other - Chain & & & 1 & & & 1 \\
\hline Other - Decoration & 1 & & & & & 1 \\
\hline Other - Scrap & 22 & 19 & 1 & 1 & 14 & 57 \\
\hline Tool/Fasteners - Bracket & & & 1 & & & 1 \\
\hline Tool/Fasteners - Screw & 1 & & & & & 1 \\
\hline Tool/Fasteners - Stake & & & 2 & & & 2 \\
\hline Tool/Fasteners - Washer & 1 & & & & & 1 \\
\hline Wire & 6 & & & & & 6 \\
\hline Metal Total & 32 & 27 & 6 & 2 & 23 & 90 \\
\hline \multicolumn{7}{|l|}{ Organics } \\
\hline Bone & 1 & 2 & 3 & 1 & 1 & 8 \\
\hline Wood & & & 1 & & & 1 \\
\hline Organics Total & 1 & 2 & 4 & 1 & 1 & 9 \\
\hline \multicolumn{7}{|l|}{ Other } \\
\hline Other - Battery Core & & 1 & & & & 1 \\
\hline Other - Slate & & 2 & & & & 2 \\
\hline Other Total & & 3 & & & & 3 \\
\hline
\end{tabular}


Table 4-4. Artifacts Recovered from Test Unit 3 above Feature 2 continued....

\begin{tabular}{|c|c|c|c|c|c|c|}
\hline Artifacts - Count & $\begin{array}{c}\text { Lev. } 1 \\
(10-20 \text { cmbd) }\end{array}$ & $\begin{array}{c}\text { Lev. } 2 \\
(20-30 \mathrm{cmbd})\end{array}$ & $\begin{array}{c}\text { Lev. } 3 \\
\text { (30-40 cmbd) }\end{array}$ & $\begin{array}{c}\text { Lev. } 4 \\
(40-50 \mathrm{cmbd})\end{array}$ & $\begin{array}{c}\text { Lev. } 5 \\
\text { (50-60 cmbd) }\end{array}$ & Total Count \\
\hline $\begin{array}{l}\text { Other Ceramic - Sewer } \\
\text { Pipe }\end{array}$ & & 4 & & & & 4 \\
\hline Personal Items - Button & & 2 & 1 & & 1 & 4 \\
\hline Samples - Charcoal & & & 1 & & & 1 \\
\hline $\begin{array}{l}\text { Spanish Colonial - } \\
\text { Galera Lead Glazed }\end{array}$ & & 1 & & & & 1 \\
\hline Total Count & 88 & 69 & 29 & 7 & 30 & 223 \\
\hline
\end{tabular}

\begin{tabular}{|l|c|c|c|c|c|c|}
\hline \multirow{2}{*}{ Artifacts - Weight (g) } & $\begin{array}{c}\text { Lev. 1 } \\
(\mathbf{1 0 - 2 0} \text { cmbd) }\end{array}$ & $\begin{array}{c}\text { Lev. } 2 \\
(20-30 \text { cmbd })\end{array}$ & $\begin{array}{c}\text { Lev. } 3 \\
(30-40 \text { cmbd })\end{array}$ & $\begin{array}{c}\text { Lev. } 4 \\
(40-50 \text { cmbd })\end{array}$ & $\begin{array}{c}\text { Lev. } 5 \\
(50-60 \text { cmbd })\end{array}$ & $\begin{array}{c}\text { Total } \\
\text { Weight (g) }\end{array}$ \\
\hline
\end{tabular}

\begin{tabular}{|l|c|l|l|l|l|l|}
\hline $\begin{array}{l}\text { Building Materials - } \\
\text { Mortar }\end{array}$ & 38.48 & & & & & $\mathbf{3 8 . 4 8}$ \\
\hline
\end{tabular}

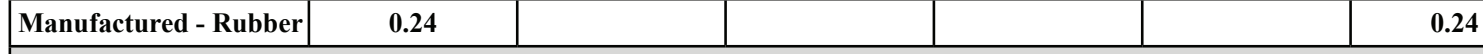

\begin{tabular}{|c|c|c|c|c|c|c|}
\hline Metal & & & & & & \\
\hline Arms - Shotgun Shell & & 0.57 & & & & 0.57 \\
\hline Cut Nails & 4.28 & 11.54 & 0.44 & 2.84 & 15.16 & 34.26 \\
\hline Other - Chain & & & 2.45 & & & 2.45 \\
\hline Other - Decoration & 0.41 & & & & & 0.41 \\
\hline Other - Scrap & 28.88 & 15.99 & 30.83 & & 16.53 & 92.23 \\
\hline Tool/Fasteners - Bracket & & & 65.04 & & & 65.04 \\
\hline Tool/Fasteners - Screw & 1.25 & & & & & 1.25 \\
\hline Tool/Fasteners - Stake & & & 33.32 & & & 33.32 \\
\hline Tool/Fasteners - Washer & 3 & & & & & 3 \\
\hline Wire & 4.47 & & & & & 4.47 \\
\hline Metal Total & 42.29 & 28.1 & 132.08 & 2.84 & 31.69 & 237 \\
\hline \multicolumn{7}{|l|}{ Organics } \\
\hline Bone & 4.99 & 95.42 & 24.13 & 10.96 & 21.05 & 156.55 \\
\hline Wood & & & 0.69 & & & 0.69 \\
\hline Organics Total & 4.99 & 95.42 & 24.82 & 10.96 & 21.05 & 157.24 \\
\hline \multicolumn{7}{|l|}{ Other } \\
\hline Battery Core & & 7.52 & & & & 7.52 \\
\hline Slate & & 1.38 & & & & 1.38 \\
\hline Other Total & & 8.9 & & & & 8.9 \\
\hline Samples - Charcoal & & & 1.02 & & & 1.02 \\
\hline Total Weight (g) & 86 & 132.42 & 157.92 & 13.8 & 52.74 & 442.88 \\
\hline
\end{tabular}


A portion of a perfume bottle was encountered in Level 2. The clear glass bottle has an embossed label that reads "TAPPAN NEW YORK." The bottle was from the Tappan Perfume Company of New York. Tappan Perfume was started circa 1881 by Herman Tappan. The bottle recovered from the unit was a simple, cylindrical bottle. Tappan's company was well known for figural bottles. Due to the growing popularity of figural bottles, Tappan had two patents on two of its designs by 1892 (Wheaton Arts 2013). The simplistic design of the bottle suggests the likelihood that it was manufactured before the figural bottles gained popularity around the turn of the century.

Ceramics recovered from the test unit consisted mainly of European wares that date from the mid-nineteenth into the twentieth century. Similar to the other units, fragments of Undecorated White Earthenware were recovered. Other ceramic types encountered included Ironstone, an unknown Lead Glazed, Semi-porcelain, and Porcelain. Undecorated White Earthenware comprises the largest portion of the ceramic assemblage (Table 4-4).

In addition to the European ceramics, one ceramic fragment associated with the Spanish Colonial Period was recovered. The Galera Lead Glazed fragment was encountered in
Level 2 (Table 4-4). The dates of manufacture spanned the Spanish Colonial Period and extended into the 1830s (Fox and Ulrich 2008).

A total of four buttons were recovered from Levels 2, 3, and 5. These buttons were made of porcelain and shell. One fragment of a porcelain doll leg was recovered in Level 1. These artifacts all appear to have a date of manufacture ranging from the mid-nineteenth to mid-twentieth century.

Similar to the other units, TU 3 contained a high number of mid-nineteenth to twentieth-century materials with very few items that pertained to the Spanish Colonial Period.

\section{Feature 1}

The apparent alignment of stones encircling an area of burned soil was identified as Feature 1. Feature 1 was located in the northern portion of TU 1 (Figure 4-2). The feature consisted of reddish yellow, burned soil that was surrounded by a semi-circular arrangement of rocks (Figure 4-7). The burned soil was compacted and difficult to break through. Artifacts were recovered from the screening of the feature

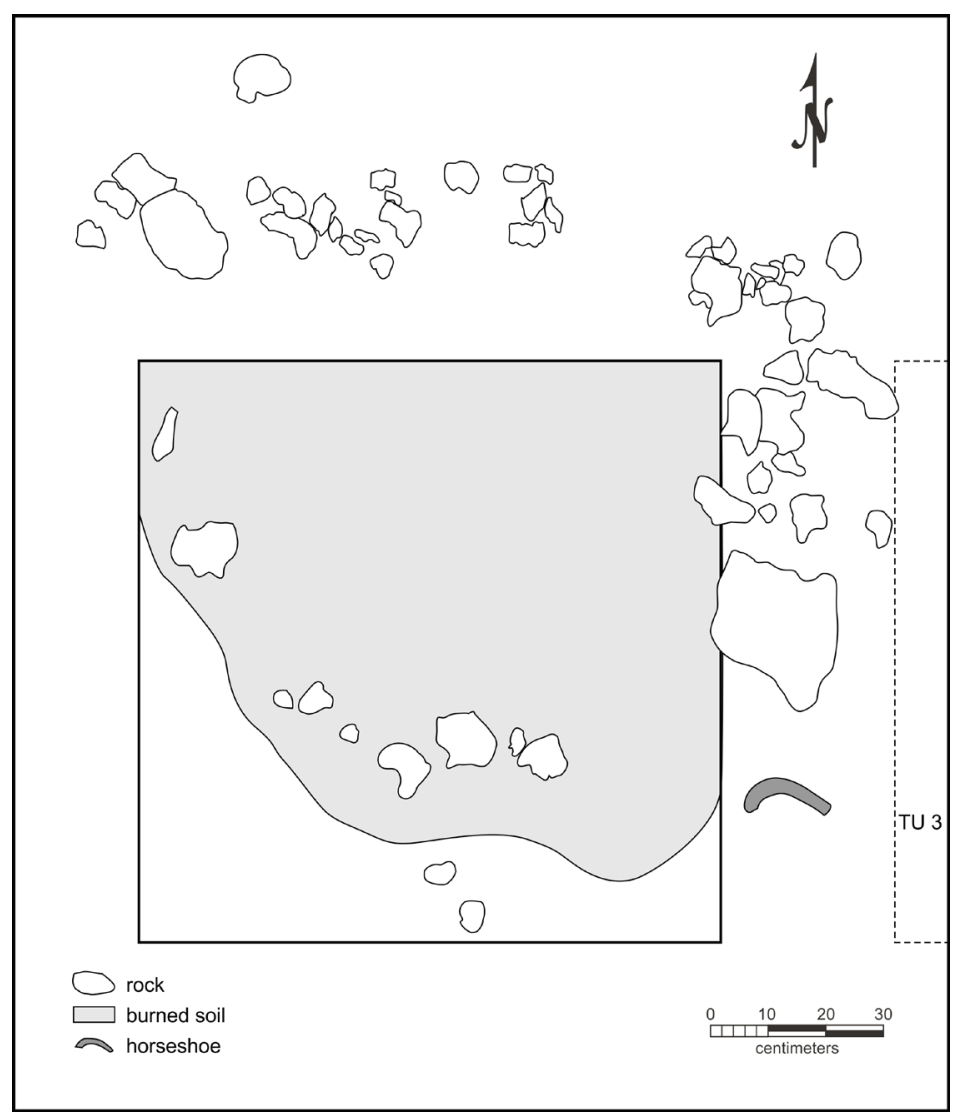

Figure 4-7. Plan view of Feature 1 in Test Unit 1. 
matrix. The burned soil extended approximately $10 \mathrm{~cm}$ in thickness and was located in Level $1(20-30 \mathrm{cmbd})$. A total of 163 artifacts were recovered from the feature matrix (Table 4-5). The artifacts encountered consisted of late nineteenthto late twentieth-century material. Glass fragments collected included aqua, brown, clear, green, red, and purple colors. Purple glass fragments are a result of using manganese to bleach the glass during manufacture. Exposure to sunlight causes the clear glass to turn purple. The use of manganese as a bleaching agent was common during the very late nineteenth century until the early twentieth century (1880-1914). The use of manganese used was discontinued at the beginning of World War I, although there were some manufactures who continued to use the material until the 1930s (Kendrick 1966).

White Earthenwares are considered a refined, hard-pasted ware that is a result of high-temperature firing in controlled kilns. In addition, these hard-paste Earthenwares exhibit a vitreous glaze and various decoration styles. The pastes of the Earthenwares can be cream, bluish, or white depending on the time period in which they were manufactured. Eleven fragments of Undecorated White Earthenware were recovered from Feature 1. White Earthenwares begin showing up in the San Antonio area as early as the mid-eighteenth century, though they did not become a popular until the nineteenth century (Fox et al. 1997).

Decorated wares that were encountered in the feature include Handpainted, Annular, and Cut Sponge. Handpainted White Earthenware is very common at historic sites throughout Texas. Dates of manufacture ranged throughout the nineteenth century, most after 1830 . The majority of these wares likely made their way into San Antonio after the arrival of the railroad in the 1870s. The wares were manufactured in England (Fox et al. 1997). Annular Ware vessels are present in San Antonio throughout the nineteenth century. The one fragment collected from the feature was solid blue. The Cut Sponge variety is also a common ceramic decoration type seen in San Antonio during the nineteenth century (Fox et al. 1997).

The feature also contained two buttons (Figure 4-8 a, b). One was made of porcelain, and the other was made of shell.

\section{Feature 2}

Feature 2 was a historic trash pit encountered in TU 3 (Figure 4-9). The top of the feature was encountered in Level 5 (50-60 $\mathrm{cmbd})$. The west wall profile exhibits the outline of a portion of Feature 2 in Levels 5, 6, and 7 (Figure 4-9). Feature 2 extended to approximately $125 \mathrm{cmbd}$ in portions of the unit.

Cultural material recovered from Feature 2 is similar to that encountered in the rest of the units. A mix of nineteenthand twentieth-century artifacts was collected, including two artifacts that could potentially date to the Spanish Colonial Period (olive glass and majolica). The majority of the material appears to fall within the late nineteenth- to the early twentieth-century range.

A variety of glass fragments was recovered during the excavations. Four chimney glass fragments were collected from Levels 6 and 7 (Table 4-6). Container glass fragments in aqua, amber, brown, clear, cobalt, and olive hues also were encountered. Aqua glass, as previously noted, became popular prior to the 1880s after which demand for clear glass increased.

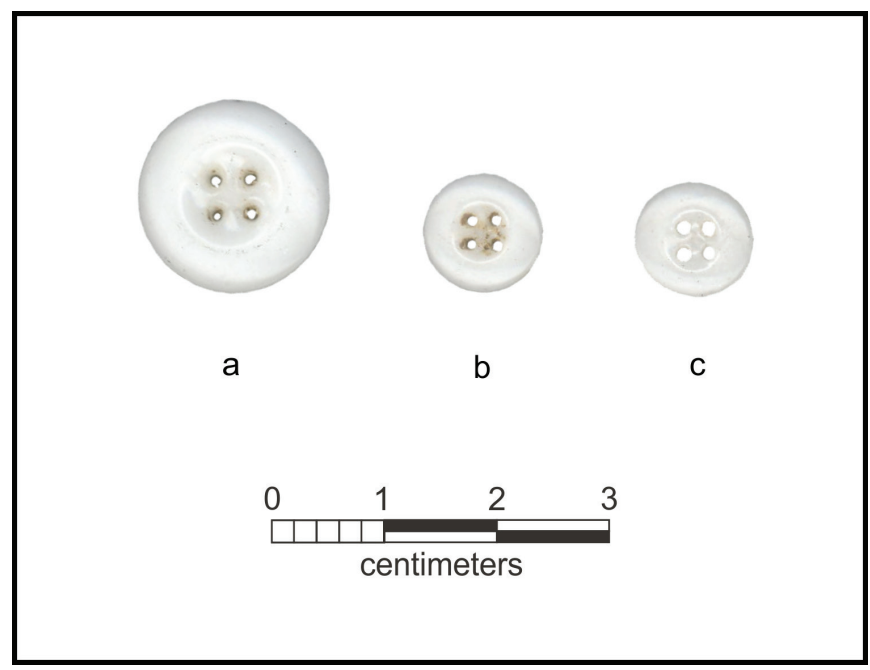

Figure 4-8. Buttons recovered from Test Unit $1(a, b)$ and Test Unit 3 (c). 
Table 4-5. Artifacts Recovered from Feature 1 (Test Unit 1, Level 1)

\begin{tabular}{|c|c|c|}
\hline Artifact & Total Count & Total Weight (g) \\
\hline Building Materials & 1 & 150.05 \\
\hline Debitage & 2 & $\mathbf{0}$ \\
\hline \multicolumn{3}{|l|}{ European Ceramics } \\
\hline Semi-porcelain & 8 & 0 \\
\hline White Earthenware - Annular Ware & 1 & 0 \\
\hline White Earthenware - Cut Sponge & 3 & 0 \\
\hline White Earthenware - Handpainted & 3 & 0 \\
\hline Undecorated White Earthenware & 11 & 0 \\
\hline European Ceramics Total & 26 & $\mathbf{0}$ \\
\hline \multicolumn{3}{|l|}{ Glass } \\
\hline Container/Vessel - Aqua & 2 & 0 \\
\hline Container/Vessel - Brown & 14 & 0 \\
\hline Container/Vessel - Clear & 9 & 0 \\
\hline Container/Vessel - Olive & 1 & 0 \\
\hline Container/Vessel - Purple & 1 & 0 \\
\hline Container/Vessel - Red & 1 & 0 \\
\hline Flat - Aqua & 5 & 0 \\
\hline Glass Total & 33 & $\mathbf{0}$ \\
\hline \multicolumn{3}{|l|}{ Metal } \\
\hline Cut Nails & 31 & 55.47 \\
\hline Other - Cast-Iron & 2 & 133.36 \\
\hline Other - Scrap & 34 & 453.01 \\
\hline Wire Nails & 1 & 0.84 \\
\hline Metal Total & 68 & 642.68 \\
\hline \multicolumn{3}{|l|}{ Organics } \\
\hline Bone & 3 & 31.56 \\
\hline Mussel Shell & 1 & 2.24 \\
\hline Organics Total & 4 & 33.8 \\
\hline \multicolumn{3}{|l|}{ Personal Items } \\
\hline Personal Fasteners - Button & 2 & 0.31 \\
\hline Personal Fasteners - Higa & 1 & 1.5 \\
\hline Toys & 1 & 0 \\
\hline Personal Items Total & 4 & 1.81 \\
\hline \multicolumn{3}{|l|}{ Samples } \\
\hline Burned Rock Samples & 22 & $1,365.13$ \\
\hline Radiocarbon Samples & 2 & \\
\hline Samples Total & 24 & $1,365.13$ \\
\hline Spanish Colonial - Tin-Glazed & 1 & $\mathbf{0}$ \\
\hline Grand Total & 163 & $2,193.47$ \\
\hline
\end{tabular}




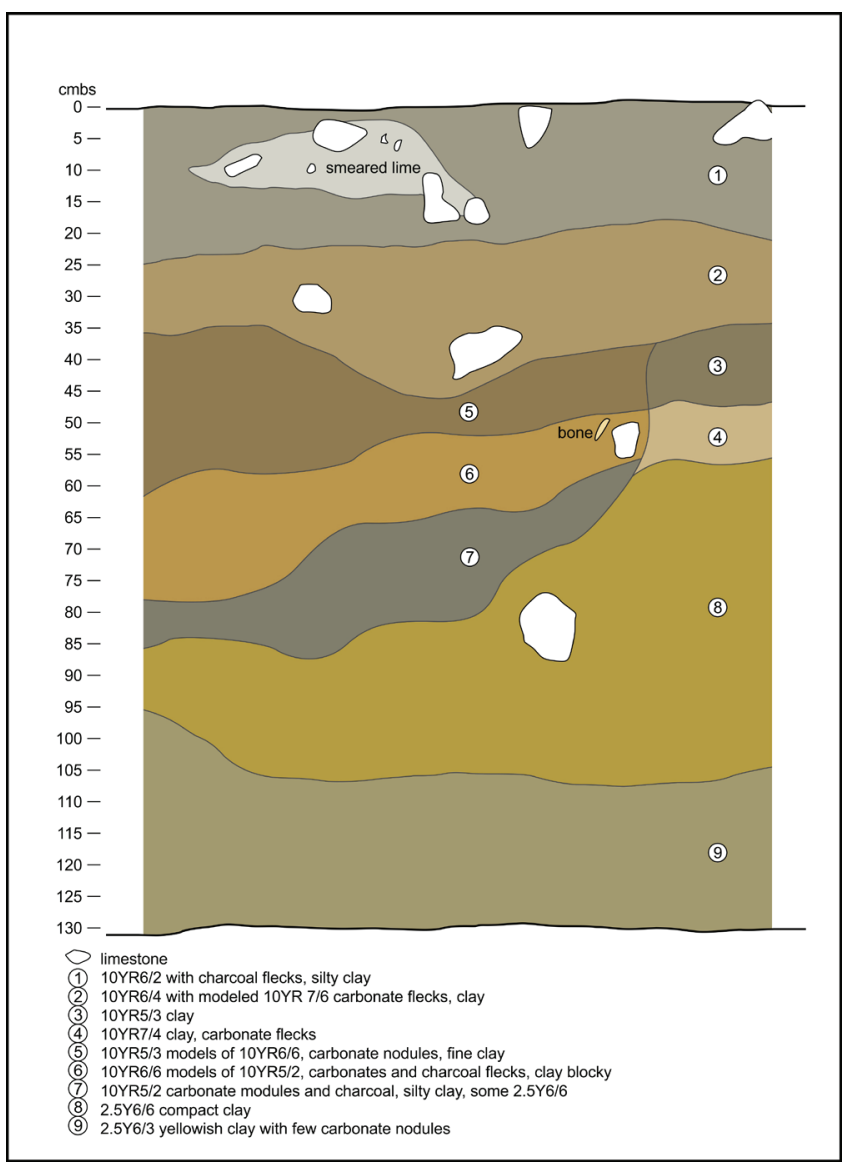

Figure 4-9. West wall profile of Test Unit 3.

Table 4-6. Artifacts Associated with Feature 2 in Test Unit 3 (Note 2)

\begin{tabular}{|c|c|c|c|c|c|c|c|c|}
\hline Artifact - Count & $\begin{array}{c}\text { Lev. } 6 \\
\text { (60-70 cmbd) }\end{array}$ & $\begin{array}{c}\text { Lev. } 7 \\
(70-80 \text { cmbd })\end{array}$ & $\begin{array}{c}\text { Lev. } 8 \\
(80-90 \text { cmbd })\end{array}$ & $\begin{array}{c}\text { Lev. } 9 \\
(90-100 \text { cmbd) }\end{array}$ & $\begin{array}{c}\text { Lev. } 10 \\
\text { (100-110 cmbd) }\end{array}$ & $\begin{array}{c}\text { Lev. } 11 \\
(110-120 \text { cmbd })\end{array}$ & $\begin{array}{c}\text { Lev. } 12 \\
(120-130 \text { cmbd) }\end{array}$ & $\begin{array}{l}\text { Total } \\
\text { Count }\end{array}$ \\
\hline Debitage & 1 & & & & 2 & & & 3 \\
\hline \multicolumn{9}{|l|}{ European Ceramics } \\
\hline Handpainted & 3 & & & & & & & 3 \\
\hline Transferware & & & & 1 & & & & 1 \\
\hline $\begin{array}{l}\text { Undecorated White } \\
\text { Earthenware }\end{array}$ & 1 & & 1 & & 4 & & & 6 \\
\hline Ironstone & & & & 2 & & 1 & & 3 \\
\hline Pipes/Figurines & 1 & & & & & 1 & & 2 \\
\hline Porcelain & & & & & 10 & & & 10 \\
\hline $\begin{array}{l}\text { European Ceramics } \\
\text { Total }\end{array}$ & 5 & & 1 & 3 & 14 & 2 & & 25 \\
\hline Stoneware & & & & & 1 & & & 1 \\
\hline \multicolumn{9}{|l|}{ Glass } \\
\hline Chimney & 2 & 2 & & & & & & 4 \\
\hline $\begin{array}{l}\text { Container/Vessel - } \\
\text { Amber }\end{array}$ & 1 & & & & & & & 1 \\
\hline
\end{tabular}


Table 4-6. Artifacts Associated with Feature 2 in Test Unit 3 continued....

\begin{tabular}{|c|c|c|c|c|c|c|c|c|}
\hline Artifact - Count & $\begin{array}{c}\text { Lev. } 6 \\
\text { (60-70 cmbd) }\end{array}$ & $\begin{array}{c}\text { Lev. } 7 \\
\text { (70-80 cmbd) }\end{array}$ & $\begin{array}{c}\text { Lev. } 8 \\
(80-90 \text { cmbd })\end{array}$ & $\begin{array}{c}\text { Lev. } 9 \\
(90-100 \text { cmbd })\end{array}$ & $\begin{array}{c}\text { Lev. } 10 \\
(100-110 \text { cmbd) }\end{array}$ & $\mid \begin{array}{c}\text { Lev. } 11 \\
(110-120 \text { cmbd) }\end{array}$ & $\begin{array}{c}\text { Lev. } 12 \\
(120-130 \text { cmbd) }\end{array}$ & $\begin{array}{l}\text { Total } \\
\text { Count }\end{array}$ \\
\hline $\begin{array}{l}\text { Container/Vessel - } \\
\text { Aqua }\end{array}$ & 1 & 1 & & & 3 & 2 & 2 & 9 \\
\hline $\begin{array}{l}\text { Container/Vessel - } \\
\text { Brown }\end{array}$ & 1 & 2 & & & 1 & 11 & 12 & 27 \\
\hline $\begin{array}{l}\text { Container/Vessel - } \\
\text { Clear }\end{array}$ & & 2 & 2 & 2 & 1 & & 1 & 8 \\
\hline $\begin{array}{l}\text { Container/Vessel - } \\
\text { Cobalt }\end{array}$ & & & & 7 & & & & 7 \\
\hline $\begin{array}{l}\text { Container/Vessel - } \\
\text { Olive }\end{array}$ & & & & & & 1 & & 1 \\
\hline Flat - Aqua & & 3 & 1 & & 2 & & & 6 \\
\hline Glass Total & 5 & 10 & 3 & 9 & 7 & 14 & 15 & 63 \\
\hline \multicolumn{9}{|l|}{ Metal } \\
\hline Cut Nails & & & 1 & 11 & & 6 & 2 & 20 \\
\hline Tack related & & 1 & & & & & & 1 \\
\hline Other - Chain Link & & & & & 1 & & & 1 \\
\hline Other - Scrap & 16 & 70 & & 10 & & 6 & & 102 \\
\hline Other - Stove Lid & & & 1 & & & & & 1 \\
\hline Metal Total & 16 & 71 & 2 & 21 & 1 & 12 & 2 & 125 \\
\hline Organics - Bone & 1 & 1 & 2 & 1 & 2 & & 1 & 8 \\
\hline \multicolumn{9}{|l|}{ Personal Items } \\
\hline Button & 1 & & & & & & & 1 \\
\hline China Marble & & & & 1 & & & & 1 \\
\hline Personal Items Total & 1 & & & 1 & & & & 2 \\
\hline Samples - Charcoal & 1 & 1 & 1 & 1 & & & & 4 \\
\hline $\begin{array}{l}\text { Spanish Colonial - } \\
\text { Tin-Glazed Puebla } \\
\text { Blue on White }\end{array}$ & & & 1 & & & & & 1 \\
\hline Total Count & 29 & 83 & 10 & 36 & 27 & 28 & 18 & 232 \\
\hline
\end{tabular}

\begin{tabular}{|c|c|c|c|c|c|c|c|c|}
\hline Artifact - Weight (g) & $\begin{array}{c}\text { Lev. } 6 \\
\text { (60-70 cmbd) }\end{array}$ & $\begin{array}{c}\text { Lev. } 7 \\
\text { (70-80 cmbd) }\end{array}$ & $\begin{array}{c}\text { Lev. } 8 \\
(80-90 \text { cmbd })\end{array}$ & $\begin{array}{c}\text { Lev. } 9 \\
(90-100 \text { cmbd) }\end{array}$ & $\begin{array}{c}\text { Lev. } 10 \\
(100-110 \text { cmbd) }\end{array}$ & $\begin{array}{c}\text { Lev. } 11 \\
(110-120 \text { cmbd })\end{array}$ & $\begin{array}{c}\text { Lev. } 12 \\
\text { (120-130 cmbd) }\end{array}$ & $\begin{array}{c}\text { Total } \\
\text { Weight } \\
\text { (g) }\end{array}$ \\
\hline \multicolumn{9}{|l|}{ Metal } \\
\hline Cut Nails & & & 3.51 & 23.88 & & 12.88 & 4.85 & 45.12 \\
\hline Tack related & & 0.47 & & & & & & 0.47 \\
\hline Other - Chain Link & & & & & 7.62 & & & 7.62 \\
\hline Other - Scrap & 28.02 & 73.71 & & 6.92 & & 17.08 & & 125.73 \\
\hline Other - Stove Lid & & & 1,334 & & & & & 1,334 \\
\hline Metal Total & 28.02 & 74.18 & $1,337.51$ & 30.8 & 7.62 & 29.96 & 4.85 & $1,512.94$ \\
\hline Organics - Bone & 8.99 & 23.87 & 13.12 & 0.13 & 25.46 & & 31.75 & 103.32 \\
\hline Samples - Charcoal & 0.48 & 0.33 & 1.17 & 0.41 & & & & 2.39 \\
\hline Total Weight (g) & 37.49 & 98.38 & $1,351.8$ & 31.34 & 33.08 & 29.96 & 36.6 & $1,618.65$ \\
\hline
\end{tabular}


Amber glass was a result of the shift from using manganese to using selenium to produce a clear, colorless glass. In the United States, the main supplier of manganese was Germany. The advent of World War I virtually cut off the supply of manganese to the States (Kendrick 1966). The glass makers had found that selenium produced the same results. Manganese bleached vessels purpled when exposed to UV rays, but selenium bleach vessels turned amber. Some researchers confuse this type with the color of beer bottles, but amber is less brown and more of a honey color. One fragment of amber glass was recovered in Level 6 .

Cobalt blue glass is typically found in lower numbers at historic sites due to its rarity. Although the color type is rare, its utility in dating the glass fragments is limited. Cobalt glass was used in a variety of different bottle types and spans such a large time period that fragments cannot be easily analyzed (Lindsey 2013). Seven fragments of cobalt glass were recovered in Level 9.

One fragment of olive glass was recovered from Level 11 (Table 4-6). Olive glass is often associated with the Spanish Colonial Period, although it has been used in the manufacture of wine and champagne bottles to this day (Lindsey 2013).

Ceramics recovered from the feature consisted mainly of European wares that date from the mid-nineteenth to into the twentieth century. European wares encountered included White Earthenware types such as Handpainted, Transfer, and Undecorated White Earthenwares. Other ceramic types encountered included Ironstone, Stoneware, and porcelain. The highest quantity of porcelain was recovered in Level 10 .

One fragment of Puebla Blue on White majolica was recovered from Level 8 (Figure 4-10). Puebla Blue on White is a common variety of majolica that was manufactured throughout the Spanish Colonial Period and into the 1830s (Fox and Ulrich 2008).

Other items of interest that were recovered from Feature 2 included ceramic figurines, a button, and a marble. Two porcelain figurines were collected from in Feature 2. The first, encountered in Level 6, was a porcelain dog figurine (Figure 4-11). The head is missing, but it appears that the figure is that of a greyhound. The porcelain is matte with green paint at the base for grass, and there are remnants of color on the dog. No maker's mark is present on the base. It resembles nineteenth-century Staffordshire examples, though it lacks gilding. The second figurine was recovered in Level 11. The porcelain boy wearing lederhosen and holding his hat behind him exhibits a glaze (Figure 4-12). This figurine may be a

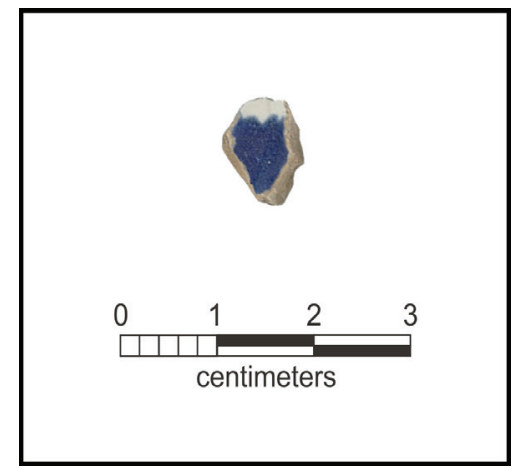

Figure 4-10. Fragment of Puebla

Blue on White majolica recovered from Feature 2.

possible Frozen Charlotte, which was a common toy for girls during the late nineteenth and early twentieth century. Frozen Charlottes were porcelain dolls that were cast in one piece, having the arms and legs "frozen" in one position (Fox et al. 1997). No color was noted on the figure. The figurine's base was missing, therefore it could not be determined if the object was a toy. One small, four-holed, porcelain button was recovered in Level 6 (Figure 4-8 c). One glazed china marble was recovered from Level 9 (Figure 4-13). This type of marble is made of porcelain and commonly exhibited handpainted lines encircling the equator (Baumann 2004).

\section{Shovel Tests within 41BX1968}

Eleven shovel tests were excavated on property owned by the Christopher Columbus Italian Society designated as site 41BX1968 (Figure 4-1). The shovel tests were used to determine if additional Spanish Colonial material was located down the slope from the artifacts exposed on the surface and behind the church. Five (45 percent) of these shovel tests contained historic material. Thirty-six artifacts were collected, and the majority of the artifacts consisted of glass fragments.

One shovel test (ST 25) contained a fragment of olive glass (Table 4-7). The glass fragment was recovered between 20 and $30 \mathrm{cmbs}$. Another fragment of olive glass was recovered from the surface just behind the church. Both of these fragments could potentially have originated in the Spanish Colonial Period, but the manufacture of this color of glass continued until the end of the nineteenth century (Lindsey 2013). A bone fragment (10.11 g) was collected from ST 24 , and another bone fragment was collected from ST $32(1.47$ g). The remainder of the artifacts encountered dates to the mid-nineteenth through the twentieth century. 


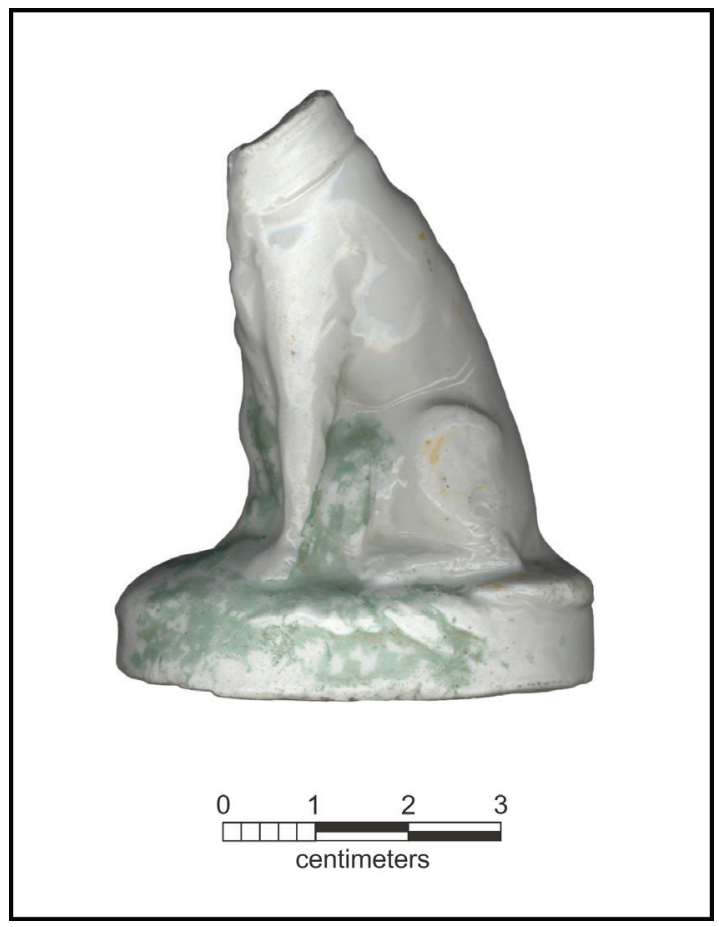

Figure 4-11. Porcelain dog figurine recovered from Feature 2.

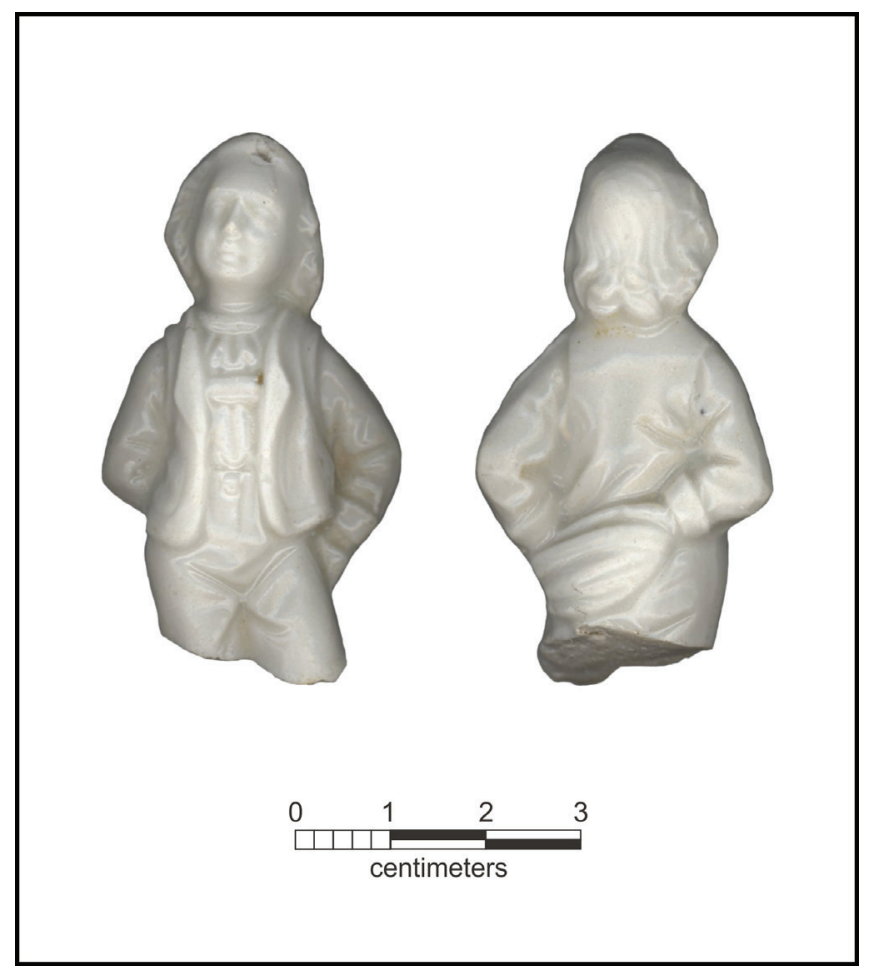

Figure 4-12. Porcelain boy figurine recovered from Feature 2.

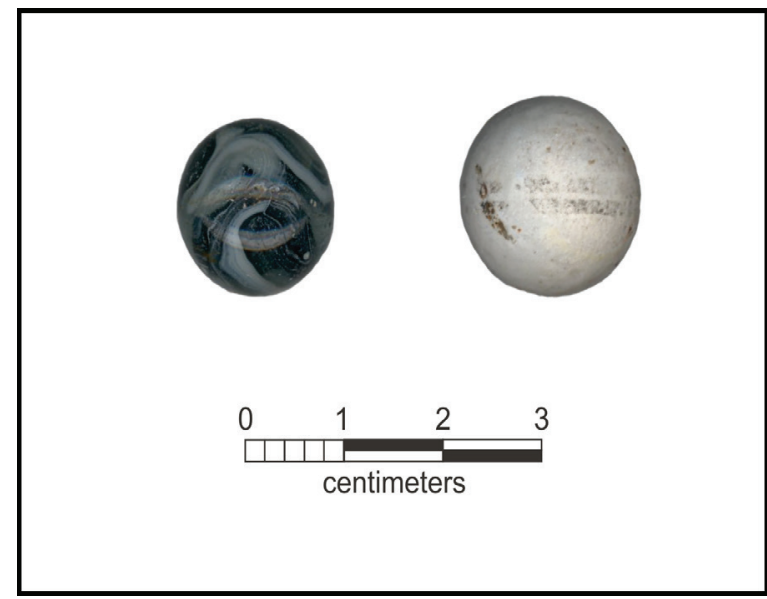

Figure 4-13. Marbles recovered from the excavations. The glass marble was from Test Unit 2. The china marble was from Feature 2 in Test Unit 3. 
Table 4-7. Artifacts Recovered from Shovel Tests on Christopher Columbus Italian Society's Property

\begin{tabular}{|c|c|c|c|c|c|c|c|c|c|c|c|}
\hline \multirow{2}{*}{ Artifact - Count } & \multirow{2}{*}{$\begin{array}{l}\text { Behind } \\
\text { Church }\end{array}$} & \multicolumn{2}{|c|}{ Shovel Test 21} & \multicolumn{3}{|c|}{ Shovel Test 24} & \multicolumn{2}{|c|}{ Shovel Test 25} & \multirow{2}{*}{$\begin{array}{c}\begin{array}{c}\text { Shovel } \\
\text { Test } 26\end{array} \\
20-30 \\
\text { cmbs }\end{array}$} & \multirow{2}{*}{$\begin{array}{l}\text { Shovel } \\
\text { Test } 32\end{array}$} & \multirow{2}{*}{$\begin{array}{c}\text { Total } \\
\text { Count }\end{array}$} \\
\hline & & $\begin{array}{c}0-10 \\
\text { cmbs }\end{array}$ & $\begin{array}{l}20-30 \\
\text { cmbs }\end{array}$ & $\begin{array}{c}0-10 \\
\text { cmbs }\end{array}$ & $\begin{array}{l}10-20 \\
\text { cmbs }\end{array}$ & $\begin{array}{l}20-30 \\
\text { cmbs }\end{array}$ & $\begin{array}{l}20-30 \\
\text { cmbs }\end{array}$ & $\begin{array}{l}50-60 \\
\mathrm{cmbs}\end{array}$ & & & \\
\hline Chipped Stone - Debitage & & 1 & & & & & & & & & 1 \\
\hline $\begin{array}{l}\text { European Ceramics } \\
\text { - Undecorated White } \\
\text { Earthenware }\end{array}$ & & & & & 1 & & 2 & & & & 3 \\
\hline \multicolumn{12}{|l|}{ Glass } \\
\hline Container/Vessel - Aqua & & & & 1 & & & 2 & & & & 3 \\
\hline Container/Vessel - Brown & & 1 & 1 & 1 & & 1 & 2 & & & & 6 \\
\hline Container/Vessel - Clear & & & 1 & 2 & & 3 & 2 & & & & 8 \\
\hline Container/Vessel - Green & & & & & & 1 & 1 & & & & 2 \\
\hline Container/Vessel - Olive & 1 & & & & & & 1 & & & & 2 \\
\hline Flat - Aqua & & 1 & & & & & & & 1 & & 2 \\
\hline Flat - Clear & & 1 & 1 & 1 & & & 1 & 2 & & & 6 \\
\hline Glass Total & 1 & 3 & 3 & 5 & & 5 & 9 & 2 & 1 & & 29 \\
\hline Metal - Wire Nail & & & 1 & & & & & & & & 1 \\
\hline Organics - Bone & & & & & & 1 & & & & 1 & 2 \\
\hline Total Count & 1 & 4 & 4 & 5 & 1 & 6 & 11 & 2 & 1 & 1 & 36 \\
\hline
\end{tabular}




\section{Chapter 5: Summary and Recommendations}

Limited archaeological investigations were conducted by the Center for Archeological Research of The University of Texas at San Antonio in effort to determine whether cultural deposits and an apparent feature noted on property owned by the Christopher Columbus Italian Society represent evidence of the original location of Mission San Antonio de Valero. Thirty-one shovel tests and three test units were excavated within Columbus Park and on property owned by the Christopher Columbus Italian Society. Twenty of the shovel tests were excavated within Christopher Columbus Park, and eleven shovel tests were placed on the property located to the north of the church. This property is owned by the Christopher Columbus Italian Society. The location was designated as site 41BX1968.

The shovel tests excavated within Columbus Park revealed no intact Spanish Colonial deposit to a depth of $60 \mathrm{~cm}$ below surface. The dark, humus rich soil encountered within the park may have been brought in at an earlier date to help with the landscaping. All artifacts that were encountered within the shovel tests are twentieth-century or modern materials. These artifacts were returned to the CAR laboratory and processed for analysis. The artifacts recovered from the Columbus Park shovel tests are permanently curated at the CAR laboratory.

Excavations at site 41BX1968 consisted of the three test units and eleven shovel tests. Very few artifacts that may potentially date to the Spanish Colonial Period were encountered at the site during the archaeological investigations $(n=63)$. Surface collection prior to the start of the project encountered artifacts that could potentially date from the early-to-lateeighteenth century. Table 1-1 lists the artifacts collected from the surface prior to and during the archaeological investigations. The temporal affiliation of the artifacts also was provided in the table. Combined with the information gathered from Table 1-1 and the analysis of the artifacts collected during the investigations, Table 5-1 displays the potential Spanish Colonial artifacts that were recovered at the site $(n=84)$. Though diagnostic, none of the material could be definitively linked to the first site of Mission Valero. The test units appear to have encountered mostly material from the nineteenth-century neighborhood that had occupied the area. A few fragments of Galera Lead Glazed and Puebla Blue on White wares were recovered from the units. While these are typically associated with the Spanish Colonial occupation, the lengthy manufacturing period for these wares makes it difficult to determine that these are specifically from the original site of Mission Valero. In addition, the ceramic types and olive glass artifacts that could be considered Spanish Colonial were recovered from mixed context, coming from levels that contained nineteenth- and twentieth-century material, and therefore, it is difficult to securely identify them as representative of an early occupation associated with the first mission. Although Table 5-1 clearly indicates that there are artifacts in the Spanish Colonial Period, deposits are mixed. CAR cannot conclude that these material derive from the occupation of the first location of the Mission Valero.

The materials recovered offer a glimpse of the nineteenthand twentieth-century neighborhood that had once stood on the property. They reveal a typical household assemblage containing nails, ceramics, and glass fragments. In addition, a few items were recovered indicated that the household contained children. Marbles and a potential porcelain doll of the Frozen Charlotte variety would have been used by children. It would appear based on the ceramic fragments, the perfume bottle, and the ceramic buttons that household members were part of the middle class of San Antonio.

The Christopher Columbus Italian Society has plans to develop the property located north of the church. This property is on a downward slope toward San Pedro Creek. San Francesco di Paola Catholic Church appears to be at the high point of the hill overlooking the creek. It is likely that if the first location of Mission Valero was on this hill the church currently sits on top of the site. Examination of the grounds in the immediate vicinity reveal that there is ample amount of cultural material on the surface in the area where the test units were placed. Cultural material was also noted on the surface just behind the church. The material is a mix of eighteenth-, nineteenth-, and twentieth-century artifacts, with the majority dating to the late nineteenth to the early twentieth century. Subsurface investigations found that the cultural material was mostly from the late nineteenth to the early twentieth century, with a small number that could be from the Spanish Colonial Period. It is possible that further investigations could either prove or refute the claim that the site is the first location of Mission Valero. Although, investigations would have to be conducted on property that is currently owned by the Archdiocese and be located in areas immediately adjacent to and under the current church. Kay Hindes, City of San Antonio Archaeologist, had been told by longtime church parishioner that artifacts were encountered while additions to the church were done during the 1950s. The artifacts were then put back under the church and on the knoll where the Spanish Colonial artifacts had been recently collected on the surface of the site. 
Table 5-1. Artifacts Collected at the Site Potentially Associated with the Spanish Colonial Period

\begin{tabular}{|c|c|c|c|c|c|c|}
\hline & Chipped Stone & Glass (Olive) & Jewelry/Beads & Ceramics & $\begin{array}{c}\text { Forged-Iron } \\
\text { Fasteners } \\
\end{array}$ & Grand Total \\
\hline \multicolumn{7}{|l|}{ Surface Collection } \\
\hline Between Units & & & 1 & 5 & & 6 \\
\hline $\begin{array}{c}\text { Prior to } \\
\text { Investigations }\end{array}$ & & & 3 & 13 & 7 & 23 \\
\hline \multicolumn{7}{|l|}{ Test Unit 1} \\
\hline Surface & 2 & & & & & 2 \\
\hline $20-30 \mathrm{cmbd}$ & 2 & 1 & 1 & & & 4 \\
\hline $30-40 \mathrm{cmbd}$ & 4 & & & & & 4 \\
\hline $40-50 \mathrm{cmbd}$ & 2 & & & 1 & & 3 \\
\hline $60-70 \mathrm{cmbd}$ & 5 & & & & & 5 \\
\hline $70-80 \mathrm{cmbd}$ & 1 & & & & & 1 \\
\hline \multicolumn{7}{|l|}{ Test Unit 2} \\
\hline $20-30 \mathrm{cmbd}$ & 6 & 1 & & 1 & & 8 \\
\hline $30-40 \mathrm{cmbd}$ & 3 & & & 6 & & 9 \\
\hline $40-50 \mathrm{cmbd}$ & 2 & 2 & & 1 & & 5 \\
\hline $50-60 \mathrm{cmbd}$ & & 1 & & 1 & & 1 \\
\hline \multicolumn{7}{|l|}{ Test Unit 3} \\
\hline $20-30 \mathrm{cmbd}$ & 3 & 1 & & 1 & & 5 \\
\hline $40-50 \mathrm{cmbd}$ & 1 & & & & & 1 \\
\hline $50-60 \mathrm{cmbd}$ & 1 & 1 & & & & 2 \\
\hline $60-70 \mathrm{cmbd}$ & 1 & & & & & 1 \\
\hline $80-90 \mathrm{cmbd}$ & & & & 1 & & 1 \\
\hline $100-110 \mathrm{cmbd}$ & 2 & & & & & 2 \\
\hline $110-120 \mathrm{cmbd}$ & & 1 & & & & 1 \\
\hline Grand Total & 35 & 7 & 5 & 30 & 7 & 84 \\
\hline
\end{tabular}

Based on the information gathered during this project, it cannot be definitely determined whether or not this location was the original site of Mission Valero. While Spanish Colonial material is present, CAR cannot conclude that these are associated with the first location of the mission. Archival research does indicate that the knoll could potentially be the first location of Mission Valero in 1718. The Spanish Colonial artifacts could date to the eighteenth century, but the majority was recovered in mixed context. In addition, the artifacts collected are of varieties of ceramics and glass that have a long span of manufacture, and this makes it difficult to firmly place the deposition of the material to the earliest occupation of San Antonio. These types are also recovered from sites that post-date the occupation of the first location of Mission Valero. Artifacts recovered from the site suggest additional investigations are needed. The discovery of additional early eighteenth-century Spanish Colonial artifacts in intact depositional contexts, coupled with architectural features that could clearly be linked to features expected at the mission would represent strong supporting evidence. Unfortunately, because much of the property is paved and because the crest of the hill has seen significant impacts from the construction of the church and hall, it will be difficult to locate buried cultural deposits and intact architectural features. Nonetheless, CAR recommends that if future opportunities arise to conduct additional excavations within the footprint of either building or under the northern parking lot, such opportunities be embraced since they may lead to the confirmation of the preliminary assessments advanced in this report. 


\section{References Cited:}

Baumann, P.

2004 Collecting Antique Marbles: Identification and Price Guide. 4th ed. Krause Publications. Iola, Wisconsin.

Bexar County Deed Records (BCDR)

2013 Electronic documents, https://gov.propertyinfo.com/tx-bexar/, accessed June 15, 2013.

Christopher Columbus Italian Society

2013 History of the Society. Christopher Columbus Italian Society. Electronic document, http://www.ccis-satx.org/ history.html, accessed January 25, 2013.

City Council Meeting Minutes (CCMM)

2013 Electronic documents, http://www.sanantonio.gov/clerk/archivesearch/AdvancedSearch.aspx, accessed June 7, 2013.

Cox, I.W.

2005 The Spanish Acequias of San Antonio. Maverick Publishing Company. San Antonio.

de la Teja, J.F.

1995 San Antonio de Bexar: A Community on New Spain's Northern Frontier. University of New Mexico Press, Albuquerque.

Fox, A.A., M. Renner, and R.J. Hard

1997 Archaeology at the Alamodome: Investigations of a San Antonio Neighborhood in Transition. Volume III: Artifacts and Special Studies. Archaeological Report, No. 238. Center for Archaeological Research, The University of Texas at San Antonio.

Fox, A.A., and K.M. Ulrich

2008 A Guide to Ceramics from Spanish Colonial Sites in Texas. Special Report, No. 33. Center for Archaeological Research, The University of Texas at San Antonio.

Habig, M.A.

1968 The Alamo Chain of Missions: A History of San Antonio's Five Old Missions. Franciscan Herald Press, Chicago.

1990 Spanish Texas Pilgrimage. Franciscan Herald Press, Chicago.

Hoffman, F.L.

1938 The Mezquía Diary of the Alarcón Expedition into Texas, 1718. Southwestern Historical Quarterly 41:312-323.

Hoffman, F.L. (translator)

1935 Diary of the Alarcón Expedition into Texas, 1718-1719 by Francisco Céliz. Vol. 5. Quivira Society Publications. Los Angeles, California.

Kendrick, G.

1966 The Antique Bottle Collector. Edward Brothers, Inc. Ann Arbor, Michigan.

Lindsey, B.

2013 Historic Glass and Bottle Identification and Information Website. Electronic document, http://www.sha.org/bottle/, accessed January 21, 2013. 
San Antonio Municipal Archives (SAMA)

2013a Subdivision, Civil Engineer Survey Book 1-Page 377 of 478. Electronic document, http://www.sanantonio.gov/ clerk/archivesearch/AdvancedSearch.aspx, accessed June 10, 2013.

2013b City Council Ordinance Book NN March 13, 1963 - March 27, 1963. Electronic document, https://webapps. sanantonio.gov/archivesearch/, accessed June 10, 2013.

Sanborn Fire Insurance Maps

2013 Digital Sanborn Maps 1867-1970. Electronic documents, http://sanborn.umi.com/, accessed June 7, 2013.

Texas Archaeological Sites Atlas (TASA)

2013 Electronic document, http://nueces.thc.state.tx.us/, accessed June 2013.

Weddle, R.S

1968 San Juan Bautista Gateway to Spanish Texas. University of Texas Press, Austin.

Wheaton Arts and Cultural Center

2013 Vanity Vessels: The Story of the American Perfume Bottle. Wheaton Arts and Cultural Center. Electronic document, http://www.wheatonarts.org/museumamericanglass/exhibitions/pastexhibitions/90-99/1999vanityvessels, accessed June 10, 2013. 


\section{Notes to Text}

\section{Raymond Mauldin CAR-UTSA}

The initial report on the CAR's work at 41BX1968 was completed in early 2014. At that time, it was distributed to the San Antonio Conservation Society, the Texas Historical Commission, the City of San Antonio's Office of Historic Preservation, the Christopher Columbus Italian Society, and a limited number of organizations. Dr. Steve Tomka served as the Principal Investigator, and Kristi Miller Nichols was the Project Archaeologist. Dr. Tomka left CAR-UTSA shortly after the report was produced. Ms. Nichols left CAR-UTSA soon after Dr. Tomka had departed. The additional copies of the original report had not been distributed prior to their departure. As THC Permit No. 6534 was not complete, I assumed the Principal Investigator role on the project. In the course of closing out the permit, a review of the original report identified several errors in analysis and presentation. Most of these were minor and have been corrected in this second printing. However, as most of the excavation took place on private land, and as the artifacts were returned to the landowner, some discrepancies could not be addressed or would have required extensive revisions. As the individuals responsible for the work were no longer at the CAR, and as the report had already been accepted by THC and partially distributed, I was reluctant to undertake extensive rewrites, especially as I did not have access to most of the artifacts, was not involved in the original work, and had not been to the site. Discussions with Dr. Tomka and comments from Ms. Nichols have greatly clarified several issues, though some still remain. Below I provide a short discussion of two problems that were not resolved in this second printing. The CAR apologizes for these errors.

Note 1 (Pages 19-20, 29-31): There are several unresolved problems with the Test Unit 1 and Feature 1 sections and with Table 4-2. The original version of this portion of the report suggested that Feature 1 was associated with Level 1 in Test Unit 1. It appears that surface material was collected and bagged prior to excavation. This material is listed as surface in both the original Table 4-2 and in Table 4-2 of this report. Level 1 (20-30 cmbd) was not listed in Table 4-2 originally, but we assume that the Feature 1 material, listed in Table 4-5, is the Level 1 material for this unit. However, Feature 1 did not cover the entire unit, as can be seen in plan and profile views (see Figures 4-2, 4-3, and 4-7) and as confirmed by the field notes on file at the CAR. The notes also suggest that artifact material was "spread throughout" the unit, though most of the material was associated with Feature 1. The notes show that two different soil samples were collected for the unit from feature and non-feature context, but there is no separation of artifacts indicated on the form. The Excel ${ }^{\circledR}$ analysis tables on file at CAR associate all artifacts from Test Unit 1, Level 1, with Feature 1. It appears, then, that feature and non-feature material were likely combined from the 10-cm level. This was done either in the field or in the lab.

Note 2 (pages 25-26, 30, 32-34): Table 4-6 and the associated text suggest that levels below Level 5 and above Level 12 in Test Unit 3 are associated with Feature 2, a historic trash pit. Figure 4-6 shows the west wall profile of Unit 3, with what is probably a basin shaped feature present in Strata 5, 6, and 7 (ca. 35-40 cm down to $85 \mathrm{cmbs}$ ). Below the bottom of Stratum 7 , there are no indications of that feature. In addition, the profile clearly shows that the feature does not cover the entire unit, being confined to the southern $75 \mathrm{~cm}$ of the $1-\mathrm{x}-0.50$-m excavation. In an attempt to resolve the contradiction shown between the profile and Table 4-6, I reviewed copies of the excavation notes on file at CAR. None of the level plan views show any feature outlines, and there is no mention of a feature in any of these notes. There are no feature forms. In addition, there is no mention of Feature 2 in the analysis tables. It is likely, then, that Feature 2 was defined in the laboratory, after fieldwork and lab analysis, and was based on the profile drawing. If my interpretation is correct, then Levels 10 through 13 (Level 13 not shown in Table 4-6) are likely well below Feature 2. Levels 5 through 9 are a mix of feature and non-feature material. Finally, Levels 1 through 4 are above Feature 2. Ms. Nichols maintains that the feature was visible in the field and did continue down to 125 $\mathrm{cm}$. She suggests that the Table 4-6 material, then, is correct as it is currently presented. 